\title{
Perinatal Exposure to a Glyphosate Pesticide Formulation Induces Liver Damage in Immature Rat Pups
}

\section{Carla Elise Heinz Rieg}

Universidade Federal de Santa Catarina

\section{Daiane Cattani}

Universidade Federal de Santa Catarina

\section{Nathalia Ferrazzo Naspolini}

Federal University of Santa Catarina: Universidade Federal de Santa Catarina

Vitoria Hayduck Cenci

Federal University of Santa Catarina: Universidade Federal de Santa Catarina

Vera Lúcia de Liz Oliveira Cavalli

Federal University of Santa Catarina: Universidade Federal de Santa Catarina

Amanda Virtuoso Jacques

Federal University of Santa Catarina: Universidade Federal de Santa Catarina

Marcus Vinicius Pereira Dos Santos Nascimento

Federal University of Santa Catarina: Universidade Federal de Santa Catarina

\section{Eduardo Monguilhott Dalmarco}

Federal University of Santa Catarina: Universidade Federal de Santa Catarina

Ana Carolina Rabello De Moraes

Federal University of Santa Catarina: Universidade Federal de Santa Catarina

Maria Claudia Santos-Silva

Universidade Federal de Santa Catarina

\section{Fatima Regina Mena Barreto Silva}

Federal University of Santa Catarina: Universidade Federal de Santa Catarina

\section{Eduardo Benedetti Parisotto}

Federal University of Santa Catarina: Universidade Federal de Santa Catarina

Ariane Zamoner ( $\square$ arianezps@gmail.com )

Universidade Federal de Santa Catarina https://orcid.org/0000-0003-2844-8563

\section{Research Article}

Keywords: liver, glyphosate, hepatotoxicity, oxidative stress, iron overload, calcium 
Posted Date: August 18th, 2021

DOl: https://doi.org/10.21203/rs.3.rs-780995/v1

License: (c) (i) This work is licensed under a Creative Commons Attribution 4.0 International License. Read Full License 


\section{Abstract}

The present study investigated the effects of perinatal exposure to glyphosate-based herbicide (GBH) on liver of immature Wistar rats. Female rats were exposed to GBH (70 mg glyphosate/ $\mathrm{Kg}$ body weight/day) in drinking water from gestation day 5 and continually up to lactation day 15 . The perinatal exposure to GBH increased ${ }^{45} \mathrm{Ca}^{2+}$ influx in offspring's liver Pharmacological tools indicated a role played by oxidative stress, phospholipase $\mathrm{C}$ (PLC) and Akt pathways, as well as voltage-dependent $\mathrm{Ca}^{2+}$ channel modulation to $\mathrm{GBH}$-induced $\mathrm{Ca}^{2+}$ influx in liver. In addition, changes in the enzymatic antioxidant defense system, decreased GSH content, lipid peroxidation and protein carbonylation suggest a connection between GBH hepatotoxic mechanism and redox imbalance. The perinatal exposure to $\mathrm{GBH}$ also increased the enzymatic activities of transaminases and gamma-glutamyl transferase in offspring's liver and blood, suggesting a pesticide-induced liver injury. Moreover, we detected increased iron levels in liver, blood and bone marrow of GBH-exposed rats, which were accompanied by increased transferrin saturation and decreased transferrin levels in blood. The levels of tumor necrosis factor- $a$ (TNF-a) and interleukin-6 (IL-6) were increased in the liver of rats exposed to $\mathrm{GBH}$. We also detected increased phospho-p65NFkB immunocontent, corresponding to the active form of this transcription factor. Therefore, we propose that excessive amounts of iron induced by perinatal exposure to GBH in offspring's liver, blood and bone marrow may account for iron-driven hepatotoxicity, which was associated with $\mathrm{Ca}^{2+}$ influx, oxidative damage and inflammation in immature rats. Further studies will clarify whether these events can ultimately impact on liver function.

\section{Introduction}

Commercial formulations containing glyphosate (N-phosphonomethyl-glycine) are the widely used herbicides in agriculture, accounting for about $60 \%$ of the world market of non-selective herbicides (IBAMA 2014, 2019). Total worldwide glyphosate use (agricultural plus non-agricultural) grew more than 12-fold from 1995 to 2014 . Over the last decade, after a variety genetically engineered glyphosate-tolerant crops were approved for planting, the global use of this herbicide increased (Benbrook 2016).

Several regulatory agencies and scientific institutions worldwide have reviewed the data on the safety of the herbicide glyphosate and its commercial formulations. Considering the intensive use of glyphosate in agricultural production, several groups are now investigating the potential toxic effects of glyphosate in different cell types. It has been proposed that there is a linkage between exposure to GBH and health effects, such as cancer (Guyton et al. 2015; IARC 2015; Myers et al. 2016; Portier 2020), endocrine disruption (de Liz Oliveira Cavalli et al. 2013; Walsh et al. 2000; Cassault-Meyer et al. 2014; Romano et al. 2021), developmental neurotoxicity (Cattani et al. 2014; Cattani et al. 2017) as well as liver and kidney toxicity (Mesnage et al. 2015).

The perinatal period is known to be a susceptible period for adverse health effects of environmental exposure. However, the consequences of perinatal occupational and environmental exposures to GBH in children's health outcomes were not fully understood. In this context, Paganelli and coworkers (2010) 
demonstrated that $\mathrm{GBH}$ produces teratogenic effects on vertebrates by impairing retinoic acid signaling. Moreover, our group showed potentially harmful impact of perinatal exposure to GBH leading to glutamate excitotoxicity, calcium overload and oxidative damage in immature (Cattani et al. 2014) and adult rat hippocampus (Cattani et al. 2017). The neurotoxicity induced by perinatal GBH exposure was related to depressive-like behavior in adult rats. Therefore, the possible role played by perinatal exposure to GBH on the onset of adverse outcomes later in life, show an urgent need for research to understand the impact of early life exposure to this herbicide to ensure well-being across life stages.

It is widely recognized that the liver is the major organ affected by xenobiotic exposure, and, experimental studies have demonstrated that exposure to $\mathrm{GBH}$ or glyphosate itself may have a hepatotoxic potential and may cause liver injury (Soudani et al. 2019; Milić et al. 2018; Mesnage et al. 2017; Tizhe et al. 2020). A previous study demonstrated that chronic ultra-low dose of Roundup ${ }^{\circledR}$ leads to rat liver and kidney damage (Mesnage et al. 2015). Pathological changes in iron levels and oxidative stress was shown to be involved in the mechanisms of glyphosate hepatotoxicity (Tang et al. 2017). It was also demonstrated that chronic prenatal exposure to glyphosate in mice can result in hepatic lipid metabolism disruption in the offspring (Ren et al. 2019). Oxidative stress and iron overload are important biomarkers of hepatic function, being important targets for biomonitoring glyphosate exposure.

This study was designed to investigate the effect of perinatal exposure to GBH on calcium influx, oxidative status, inflammatory parameters and iron concentrations in liver, blood, and bone marrow of 15days-old rats. We propose that the mechanisms underlying the hepatotoxic effects of perinatal exposure

to $\mathrm{GBH}$ in immature rat liver might be mediated by $\mathrm{Ca}^{2+}$ influx, iron accumulation, oxidative imbalance and inflammation. We hypothesize that the increased intracellular $\mathrm{Ca}^{2+}$ levels and iron accumulation could be orchestrating an iron-driven hepatotoxicity targeting relevant aspects of hepatic cell function.

\section{Materials And Methods}

\subsection{Radiochemical and compounds}

${ }^{45} \mathrm{CaCl}_{2}$ (specific activity of $321 \mathrm{kBq} / \mathrm{mg}$ of $\mathrm{Ca}^{2+}$ ) and Optiphase HiSafe III biodegradable liquid scintillation were purchased from PerkinElmer (Waltham, MA, USA). The herbicide Roundup Original ${ }^{\circledR}$ containing glyphosate $360 \mathrm{~g} / \mathrm{L}$ is a commercial formulation registered in the Brazilian Ministry of Agriculture, Livestock and Supply (Ministério da Agricultura, Pecuária e Abastecimento - MAPA). The glucose-6-phosphate dehydrogenase (G6PD) assay kit was kindly provided by Intercientífica (São José dos Campos, SP, Brazil). The NF-kB p65 (Total) InstantOne ELISA and InstantOnePhospho-NF-kB p65 (Ser536) ELISA kits were purchased from eBioscience® (San Diego, CA, USA). The reagents related to the analysis of biomarkers of oxidative stress and enzyme inhibitors LY294002, U73122, nifedipine and Nacetylcysteine (NAC) were purchased from Sigma Chemical Company (St. Louis, MO, USA). All other chemicals were of analytical grade.

\subsection{Animals}


Wistar rats were bred and maintained in an air-conditioned room (about $21^{\circ} \mathrm{C}$ ) with controlled lighting $(12$ $\mathrm{h} / 12 \mathrm{~h}$ light/dark cycle). Wistar rats were mated and the day of appearance of the vaginal plug was considered day 0 of fetal age. On the day of birth, the litter size was culled to eight pups. The suckling rats were kept with their mothers until euthanasia. Fifteen-day-old pups were used in all experimental protocols. Pelleted food (Nuvital, Nuvilab CR1, Curitiba, PR, Brazil) and tap water were available ad libitum. All animals were observed for clinical signs of toxicity related to chemical treatment. All the animals were carefully monitored and maintained in accordance with the local Ethical Committee for Animal Use (Protocol CEUA/UFSC \#PP00820).

\subsection{Perinatal exposure to glyphosate-based herbicide}

Perinatal exposure to GBH was performed as previous published by our research group (Cattani et al. 2014; Cattani et al. 2017). In summary, pregnant female Wistar rats received the commercial formulation containing glyphosate in the drinking water from gestation day 5 and continually up to lactation day 15 at a daily dose equivalent to $70 \mathrm{mg}$ of glyphosate/Kg body mass to assess the potential harmful effects associated with perinatal exposure to GBH. Every 3 days a fresh bottle of water with GBH dissolved in it was provided. Animals receiving only water during the same period were used as controls. Williams and coworkers (2000) previously published that the limits of no observed adverse effect level (NOAEL) for maternal toxicity for glyphosate was $1000 \mathrm{mg} / \mathrm{Kg}$ body mass/day dosage, which was equivalent to 1/14 of the dose used in our study. Each experiment was carried out by treating four to six different dams during perinatal period, and the pups from their litters were used to investigate the effects of GBH on liver, blood and bone marrow of 15-day-old offspring. The treatment of dams was repeated 4 times. Drink consumption and offspring body mass were recorded daily. At parturition, the offspring number was reduced to 8 per mother. Whenever possible, equal number of male and female pups were kept within the litters. During the lactation period, the pups had free access to the nipples. Each experimental group contained blood, bone marrow and liver samples from rats of different litters. Rats were euthanized by decapitation, blood was collected, femurs were removed for bone marrow extraction, and the liver was dissected onto Petri dishes placed on ice. Head-to-anus lengths and umbilical waist circumference were recorded. The body and liver weighs were used to calculate the liver index (Liver index = liver weight/body weight). At least 8 samples from different pups were used in each experimental protocol described below.

\section{4. ${ }^{45} \mathrm{Ca}^{2+}$ uptake}

Liver slices from 15-day-old male rats were pre-incubated in Krebs-Ringer bicarbonate (KRb) buffer (122 $\mathrm{mM} \mathrm{NaCl}, 3 \mathrm{mM} \mathrm{KCl}, 1.2 \mathrm{mM} \mathrm{MgSO}_{4}, 1.3 \mathrm{mM} \mathrm{CaCl}_{2}, 0.4 \mathrm{mM} \mathrm{KH}_{2} \mathrm{PO}_{4}, 25 \mathrm{mM} \mathrm{NaHCO}_{3}$ ) for $15 \mathrm{~min}$ in a Dubnoff metabolic incubator (Thermo Fisher Scientific, Inc., Waltham, MA) at $37^{\circ} \mathrm{C}, \mathrm{pH} 7.4$ and gassed with $\mathrm{O}_{2}: \mathrm{CO}_{2}(95: 5, \mathrm{v} / \mathrm{v})$. After that, the medium was changed by fresh $\mathrm{KRb}$ with $0.1 \mu \mathrm{Ci} / \mathrm{ml}{ }^{45} \mathrm{Ca}^{2+}$ and the tissue was incubated for $30 \mathrm{~min}$. When indicated, GBH at concentrations ranging from 0.036 to $36 \mathrm{mg} / \mathrm{L}$ was added to incubation period and L-type voltage-dependent channel blocker (10 $\mu \mathrm{M}$ nifedipine), enzyme inhibitors (10 $\mu \mathrm{M}$ LY294002, $30 \mu \mathrm{M}$ PD98059, $2 \mu \mathrm{M}$ U73122) or the antioxidant NAC were added during the preincubation and incubation (see Fig. 1). Extracellular ${ }^{45} \mathrm{Ca}^{2+}$ was thoroughly washed off in a 
washing solution (127.5 mM NaCl, $4.6 \mathrm{mM} \mathrm{KCl}, 1.2 \mathrm{mM} \mathrm{MgSO}_{4}, 10 \mathrm{mM}$ HEPES, $11 \mathrm{mM}$ glucose, and 10 $\mathrm{mM} \mathrm{LaCl}_{3}, \mathrm{pH}$ 7.3) to prevent release of the intracellular ${ }^{45} \mathrm{Ca}^{2+}$ (Zamoner et al. 2007). Then, tissue slices were digested and homogenized with $0.5 \mathrm{M} \mathrm{NaOH}$, aliquots were placed in scintillation fluid and counted in a LKB RackBeta liquid scintillation spectrometer (model LS 6500 Multi-Purpose Scintillation Counter, Beckman Coulter, Boston, MA). The results were expressed as $\mathrm{pmol}^{45} \mathrm{Ca}^{2+} / \mathrm{mg}$ protein or $\%$ of control.

\subsection{Detection of ROS}

Reactive oxygen species (ROS) formation was measured using the cell permeable probe 2',7'dichlorodihydrofluorescein diacetate $\left(\mathrm{H}_{2} \mathrm{DCFDA}\right)$. Cellular esterases hydrolyze the probe to nonfluorescent 2',7'dichlorodihydrofluorescein ( $\left.\mathrm{H}_{2} \mathrm{DCF}\right)$, which is retained in the cells. In the presence of ROS and cell peroxidases, H2DCF is transformed into the 2',7'-dichlorofluorescein (DCF), highly fluorescent substance (Halliwell and Whiteman 2004). Liver slices were homogenized in a cold buffer containing 20 $\mathrm{mM}$ sodium phosphate $\mathrm{pH} 7.4$ and $140 \mathrm{mM} \mathrm{KCl}$, followed by centrifugation ( $960 \mathrm{xg}$ at $4^{\circ} \mathrm{C}$ for $10 \mathrm{~min}$ ). The stock solution of $1 \mathrm{mM} \mathrm{H}$ 2DCFDA was prepared in DMSO and protected from light. The supernatant was incubated in a black microplate with an aliquot of $\mathrm{H} 2 \mathrm{DCFDA}$ at $37^{\circ} \mathrm{C}$ for $30 \mathrm{~min}$. The product was detected at excitation wavelength of $485 \mathrm{~nm}$ and emission wavelength of $520 \mathrm{~nm}$. The results were expressed in arbitrary units and the values corrected by the protein concentration of each sample.

\subsection{Lipid peroxidation levels}

The detection of substances that react with thiobarbituric acid (TBARS), particularly malondialdehyde (MDA), was performed to evaluated lipid peroxidation in liver samples of rats (Bird and Draper 1984). Briefly, homogenate was precipitated with trichloroacetic acid (12\% TCA) followed by the incubation with buffer $60 \mathrm{mM}$ Tris- $\mathrm{HCl} \mathrm{pH} 7.4$ (0.1 mM diethylenetriaminepentaacetic acid [DPTA]) and 0.73\% thiobarbituric acid, at $100^{\circ} \mathrm{C}$, for $60 \mathrm{~min}$. After cooling, the samples were centrifuged ( $5 \mathrm{~min}$ at $10,000 \times \mathrm{g}$ ) and the absorbance of the chromophore was measured at $535 \mathrm{~nm}$. Aliquots of liver homogenate were used to analyze the protein concentration. Determinations were expressed in nmol MDA/mg protein.

\subsection{Protein carbonyl assay}

To determine the oxidative damage to proteins by carbonylation soluble protein was reacted with $10 \mathrm{mM}$ 2,4-dinitrophenyl-hydrazine (DPNH) in $2 \mathrm{M}$ hydrochloric acid for $1 \mathrm{~h}$ at room temperature in the dark and precipitated with $20 \%$ TCA. After centrifugation $(11,000 \mathrm{xg}$ for $5 \mathrm{~min})$ the protein pellet was washed three times by resuspension in ethanol/ethyl acetate (1/1). Proteins were then solubilized in $6 \mathrm{M}$ guanidine hydrochloride in $20 \mathrm{mM}$ potassium phosphate and centrifuged at $14,000 \mathrm{xg}$ for $5 \mathrm{~min}$ to remove any trace of insoluble material (Levine et al. 1990). The carbonyl content was measured at $370 \mathrm{~nm}$. The total protein concentration was determined (LOWRY et al. 1951) and the protein carbonyl concentration was expressed in $\mathrm{nmol} / \mathrm{mg}$ protein.

\subsection{Reduced glutathione assay}

The reduced glutathione (GSH) levels was determined using the reagent DTNB (5,5'-dithiobis 2nitrobenzoic acid) (BEUTLER, DURON, and KELLY 1963). After being centrifuged at 5,000xg for $5 \mathrm{~min}$, the 
supernatants from the acid extracts (tricarboxylic acid [TCA] 12\%, 1:10 m/v) were added to $2.5 \mathrm{mM}$ DTNB in $0.2 \mathrm{M}$ sodium phosphate buffer $\mathrm{pH} 8.0$, and the formation of the thiolate anion of yellow color was immediately measured at $412 \mathrm{~nm}$. The GSH levels were expressed in $\mathrm{mmol} / \mathrm{g}$ protein.

\subsection{Antioxidant enzyme assays}

Liver from control or GBH-treated animals were homogenized in $0.2 \mathrm{M}$ Tris buffer, $\mathrm{pH} 7.4$, to quantify G6PD activity. To determine superoxide dismutase (SOD), catalase (CAT), glutathione peroxidase (GPx), glutathione reductase (GR) and glutathione S-transferase (GST) activities, liver was homogenized in a cold buffer containing $20 \mathrm{mM}$ sodium phosphate $\mathrm{pH} 7.4,0.1 \%$ Triton, and $150 \mathrm{mM} \mathrm{NaCl}(1: 20 \mathrm{~m} / \mathrm{v})$. The assays were performed using the supernatant after centrifugation of the homogenate $(5,000 \mathrm{xg}$ for 5 min). Sample aliquots were saved for total protein determinations (LOWRY et al. 1951).

\subsubsection{Glucose-6-phosphate dehydrogenase assay}

The NeoLISA kit provided by Intercientifica ${ }^{\circledR}$ was used to determine the G6PD. The protocol was performed following the manufacturer's instructions, with some modifications. For measuring the G6PD activity, aliquots of tissue homogenate were incubated in the presence of $\mathrm{NADP}^{+}$leading to the oxidation of glucose-6-phosphate to 6-phosphogluconate (Solem 1984). The NADPH produced was measured in a kinetic mode over $10 \mathrm{~min}$. The results were calculated by assessing the increase in the optical density per min (slope) of the sample against the "slope" of standard G6PD enzyme activity. The enzyme activity was expressed as $\mathrm{U} / \mu \mathrm{g}$ protein.

\subsubsection{Superoxide dismutase activity}

The SOD activity was analyzed according to the method previously described (Misra and Fridovich 1972), with modifications (Boveris et al. 1983). The reaction is based on the epinephrine oxidation ( $\mathrm{pH} 2.0$ to 10.2) which produces superoxide anion and adrenochrome, which is measured at $480 \mathrm{~nm}$. A unit of SOD is defined as the amount of enzyme that inhibits the speed of oxidation of adrenalin by $50 \%$, and the results were expressed in USOD/min/g protein.

\subsubsection{Catalase activity}

The CAT activity in tissue homogenates was determined by measuring the decrease in the absorbance of $10 \mathrm{mM} \mathrm{H} \mathrm{O}_{2}$ solution at $240 \mathrm{~nm}$ for 30 seconds (Aebi 1984). The enzyme activity was expressed as $\mathrm{mmol} / \mathrm{min} / \mathrm{g}$ protein.

\subsubsection{Glutathione peroxidase activity}

The GPx activity was analyzed by a method based on the tert-butyl hydroperoxide reduction via oxidation of GSH to GSSG, catalyzed by GPx, and subsequent regeneration of GSH by the enzyme GR with oxidation of NADPH at $340 \mathrm{~nm}$. Therefore, the rate of oxidation of NADPH is proportional to the activity of the GPx in the sample (Flohé and Günzler 1984). The enzyme activity was expressed as $\mu \mathrm{mol} / \mathrm{min} / \mathrm{g}$ protein. 


\subsubsection{Glutathione reductase activity}

The GR activity was determined by measuring the rate of NADPH oxidation at $340 \mathrm{~nm}$ due to the formation of GSH, from GSSG, by the action of GR present in the sample (Carlberg and Mannervik 1985). The enzyme activity was expressed as $\mu \mathrm{mol} / \mathrm{min} / \mathrm{g}$ protein.

\subsubsection{Glutathione-S-transferase activity}

The GST activity was measured using the 1-chloro-2,4-dinitrobenzene (CDNB), as substrate for GST. In this reaction, GST promotes the CDNB-GSH conjugation. This reaction was spectrophotometrically monitored for 60 seconds at $340 \mathrm{~nm}$ (Habig, Pabst, and Jakoby 1974). The enzyme activity was expressed as $\mu \mathrm{mol} / \mathrm{min} / \mathrm{g}$ protein.

\subsection{Enzymatic activity of ALT and AST}

The activities of were performed in serum and in liver. Liver samples were homogenized in cold $0.2 \mathrm{M}$ Tris buffer, $\mathrm{pH}$ 7.4. The enzymatic activity alanine aminotransferase (ALT) and aspartate aminotransferase (AST) was quantified in aliquots of the serum and liver homogenate using a colorimetric method (REITMAN and FRANKEL 1957). Results for enzyme activity were obtained using calibration curves based on non-chromogenic absorbance. The absorbance of the samples was determined in a plate reader (Tecan Infinite ${ }^{\circledR} 200$ PRO, Tecan Group Ltd., Männedorf, Switzerland) at $505 \mathrm{~nm}$. The results were expressed as $\mathrm{U} / \mathrm{L}$ (serum) or $\mathrm{U} / \mu \mathrm{g}$ protein (tissue).

\subsection{GGT assay}

Liver slices were weighed and homogenized in cold $0.1 \mathrm{M}$ Tris buffer, $\mathrm{pH} 8.5(10 \%$ homogenate, $\mathrm{m} / \mathrm{v})$ to determine GGT activity in the liver. GGT activity was measured by using l-y-glutamyl-p-nitroanilide as substrate and glycylglycine as the acceptor molecule (ORLOWSKI and MEISTER 1963). Aliquots of the serum or liver homogenate were incubated with the enzymatic substrate. The absorbance of the samples was determined in a plate reader (Tecan Infinite ${ }^{\circledR} 200 \mathrm{PRO}$ ) at $530 \mathrm{~nm}$. The results were expressed as U/L (serum) or $\mathrm{U} / \mathrm{mg}$ protein (tissue).

\subsection{Iron concentration assay}

Iron concentration was determined in serum and in liver samples. Hepatic tissue was weighed and homogenized in cold 0.2 M Tris buffer, $\mathrm{pH} 7.4(1: 10 \mathrm{~m} / \mathrm{v})$. Liver homogenates to measure the amount of iron were also normalized to the total amount of protein in each sample. Serum or liver homogenate were combined with buffer containing hydroxylamine $\mathrm{pH} 4.0$ and then ferrozine was added with subsequent incubation at $37^{\circ} \mathrm{C}$ for $10 \mathrm{~min}$. Thus, the ferric ions were dissociated from the protein by the action of acid buffer and reduced to ferrous ions by hydroxylamine. After addition of ferrozine there was the formation of a complex, whose absorbance measured at $560 \mathrm{~nm}$ is proportional to the amount of iron in the sample 
(Goodwin, Murphy, and Guillemette 1966). The values were expressed in $\mu \mathrm{g} / \mathrm{dL}$ for serum or $\mu \mathrm{g} / \mathrm{g}$ tissue for liver samples.

\subsection{Transferrin concentration assay}

Transferrin concentration was determined in serum using an immunoturbidimetric method (Kreutzer 1976). The methodology is based on addition of specific anti-transferrin antibodies in the sample, then the antibodies bind to transferrin present in serum and form an insoluble complex, which provides a turbidity whose intensity is detected at $340 \mathrm{~nm}$ and is proportional to the serum transferrin amount. Values were expressed in $\mu \mathrm{mol} / \mathrm{L}$.

\subsection{Total iron-binding capacity assay (TIBC) and transferrin saturation}

The TIBC was used as a blood test to evaluate how well transferrin can carry iron in pups' blood after perinatal exposure to glyphosate. TIBC measures the total amount of iron that can be bound by proteins in the blood. Since transferrin is the primary iron-binding protein in blood, the TIBC test is an indirect measurement of transferrin availability, which means the amount of transferrin that is available to bind to iron. To measure the TIBC in pup's blood, a known concentration of ferrous ions was incubated with the sample. The ferrous ions bind specifically with the transferrin, which under physiologic conditions is around $30 \%$ saturated. This means that about two-thirds of iron-binding capacity is held in reserve as available sites on the carrier protein. Therefore, initially, a known concentration of Iron ions was incubated with serum and will bind specifically with the Transferrin in unsaturated Iron-binding sites. The exceeding ferrous ions (unbound) were measured by the reaction with ferrozine, at a wavelength of $560 \mathrm{~nm}$. The difference between the exceeding ferrous ions and the total quantity of ferrous ions initially added to the sample is equivalent to the quantity of this ion that was bounded to transferrin, which will be the latent iron-binding capacity (LIBC) (Persijn, van der Slik, and Riethorst 1971). The TIBC was then calculated by adding the serum iron concentration to LIBC, as follows: TIBC $(\mu \mathrm{g} / \mathrm{dL})=\mathrm{LIBC}+$ Serum Iron. The TIBC was expressed in $\mu \mathrm{g} / \mathrm{dL}$. TIBC is frequently used along with a serum iron concentration to calculate transferrin saturation, a more useful indicator of iron status than just iron levels or TIBC alone, since it estimates how many of transferrin iron-binding sites are occupied. Transferrin saturation was determined dividing the iron concentration by the TIBC, as follows: Transferrin saturation $(\%)=($ Serum iron level x 100) $/$ TIBC (Yee and Zin 1971).

\subsection{Perls' Prussian blue reaction for ferric iron in bone marrow}


Pups' bone marrow was obtained from rat femurs from control and GBH-treated groups. Femurs were taken and stripped of adherent muscles of the knee end. A needle was inserted into the bone and cells were aspirated followed by several flushes through the bone using a $1 \mathrm{ml}$ syringe filled with culture medium, until all the bone marrow was flushed out of the bone. A similar procedure was performed from the other end of the bone as close to the tip as possible. Then, iron accumulation was accessed in fresh films of bone marrow by Perls' Prussian blue cytochemistry. The reaction occurs with the treatment of sections with an acid ferrocyanide solution, unmasking of ferric iron in the form of the hydroxide, $\mathrm{Fe}(\mathrm{OH})_{3}$. The ferric iron then reacts with potassium ferrocyanide to produce an insoluble bright blue pigment, ferric ferrocyanide, also called Prussian blue (a complex hydrated ferric ferrocyanide substance). The reaction was started with a mixture of 1 part $2 \%$ hydrochloric acid and 1 part $2 \%$ potassium ferrocyanide that is applied to the fresh films of marrow for $30 \mathrm{~min}$ followed by a rinse in distilled water. After that, the bone marrow slides were counterstained with $0.1 \%$ safranin for 1 min. These iron accumulation in bone marrow was then examined with a light microscope.as blue or purple deposits.

\subsection{Hematological parameters}

White blood cells (WBC) and red blood cells (RBC) were counted manually in Neubauer chamber. Briefly, anticoagulated (EDTA) blood samples were diluted 20 times with Turk's fluid for WBC count and 200 times with Dacie's fluid for RBC count. The diluted blood was added to the Neubauer chamber and cells were allowed to settle for 10 min (Dacie and Lewis 1995). WBC or RBC were counted in specific areas of the Neubauer chamber under the microscope. To determine the WBC differential, blood smear was stained with the May-Grunewald-Giemsa technique. One hundred cells were then counted and classified. Hemoglobin concentration determination was based on photometric detection of cyanmetahemoglobin (colorimetric method). Drabkin's solution and Hemoglobin Standard Solution were purchased from Labtest (Lagoa Santa, MG, Brazil) and hemoglobin concentration was determined according to the manufacturer's instructions. Absorbance was determined using a SP-22 spectrophotometer (Biospectro). Hematocrit was assessed using the microhematocrit method. Mean corpuscular volume (MCV), mean corpuscular hemoglobin $(\mathrm{MCH})$, and mean corpuscular hemoglobin concentration ( $\mathrm{MCHC}$ ) were calculated from hemoglobin, hematocrit, and RBC count.

\subsection{Quantification of Pro-Inflammatory Cytokine Levels (TNF- $a$ and IL-6) in plasma}

The tumoral necrosis factor alpha (TNF-a), and interleukin 6 (IL-6) levels in the plasma samples of pups were quantified using a commercially available enzyme-linked immunosorbent assay kit (Peprotech, Rocky Hill, NJ, USA) according to the manufacturer's instructions. Cytokine level was estimated by interpolation from the standard curve and the results are expressed in $\mathrm{pg} / \mathrm{mL}$. 


\subsection{Measurement of Total and Phosphorylated Levels of NF-KB}

To analyze effect of PQ exposure on phosphorylation of the p65 protein (subunit of NF-KB), the total and phosphorylated levels of p65 (p65 and p-p65, respectively) were measured. Hippocampus from control and PQ-treated rats was collected, homogenized in lysis buffer and protein concentration was determined (LOWRY et al. 1951). Total protein content was adjusted, and we used $60 \mu \mathrm{g} / \mathrm{sample}$. The analysis was performed using a commercially available kit with specific monoclonal antibodies against total p65 protein and specifically against phosphorylated p65 protein. The experiment was carried out using the NF-kB p65 (Total) InstantOne ELISA and InstantOnePhospho-NF-kB p65 (Ser536) ELISA Kits (purchased from eBioscience ${ }^{\circledR}$, San Diego, CA, USA), following the manufacturer's protocols. The results are expressed as the fold change relative to the control group, which represents the basal total and phosphorylated p65 levels.

\subsection{Statistical Analysis}

All experimental data are represented as mean \pm S.E.M. Statistically significant differences from controls were determined by unpaired Student's $t$-test, one-way ANOVA and post hoc tests with multiple comparisons (Bonferroni) post-tests using GraphPad Prism version 9.1.1, GraphPad software Inc, (La Jolla, California, USA). Differences were significant when $\mathrm{p}<0.05$.

\section{Results}

The experimental model of perinatal exposure to $\mathrm{GBH}$ was previously published by our research group (Cattani et al. 2014; Cattani et al. 2017). To understand, at least in part, the systemic effects of perinatal exposure to $\mathrm{GBH}$, in the present study we investigated the hepatotoxic effects of this herbicide and the mechanisms underlying such effects. All animals were monitored daily, and we did not observe visible external malformations between experimental groups. In addition, perinatal GBH exposure did not alter the average litter size or caused mortality within-litter, corroborating our previous data (Cattani et al. 2017). Table 1 showed decreased head-to-anus lengths and reduced umbilical waist circumference in pups perinatally exposed to $\mathrm{GBH}$ when compared to control group. In addition, perinatal exposure to GBH also caused a significant decrease in liver weight and liver index, indicating that herbicide impacts the liver size. These results suggest that perinatal exposure to GBH may impaired animal growth. We did not observe any differences between male and female (data not shown). 
Table 1

Effect of perinatal exposure to GBH on pup's biometric parameters.

\begin{tabular}{|c|c|c|}
\hline & Control & GBH \\
\hline Body weight (g) & $21.0 \pm 0.4$ & $18.5 \pm 0.2$ *** \\
\hline Liver weight (g) & $0.79 \pm 0.053$ & $0.52 \pm 0.04^{\star \star *}$ \\
\hline Liver index $\#$ (mg/g body weight) & $37.74 \pm 3.55$ & $28.66 \pm 2.35^{\star \star \star}$ \\
\hline Head-to-anus length (cm) & $8.97 \pm 0.09$ & $8.51 \pm 0,10 * \star \star$ \\
\hline Umbilical waist circumference $(\mathrm{cm})$ & $5.87 \pm 0.18$ & $5.23 \pm 0.09 \star \star \star$ \\
\hline \multicolumn{3}{|c|}{$\begin{array}{l}\text { Data are reported as means } \pm \text { SEM of } 10 \text { animals in each group. Statistically significant differences } \\
\text { from controls, as determined by Student's } t \text {-test, are indicated: } \star \star \star p<00.0001 \text {. }\end{array}$} \\
\hline
\end{tabular}

\subsection{Perinatal $\mathrm{GBH}$-exposure increased $\mathrm{Ca}^{2+}$ influx in liver of 15-days-old rats}

Considering that glyphosate was previously demonstrated to induce $\mathrm{Ca}^{2+}$ influx in testicular (de Liz Oliveira Cavalli et al. 2013) and hippocampal cells (Cattani et al. 2014; Cattani et al. 2017), in the present study we sought to determine if $\mathrm{GBH}$ exposure also alters $\mathrm{Ca}^{2+}$ influx in the liver. Figure $1 \mathrm{~A}$ showed that perinatal exposure to $\mathrm{GBH}$ increased ${ }^{45} \mathrm{Ca}^{2+}$ influx in the liver of immature pups. To better understand the role of calcium on GBH mechanism of toxicity, liver slices of immature rats ( 15 day old) were exposed "in vitro" to different concentrations of pesticide ranging from 0.036 to $36 \mathrm{mg} / \mathrm{L}$ and ${ }^{45} \mathrm{Ca}^{2+}$ influx was investigated. Figure 1B shows that $0.36 \mathrm{mg} / \mathrm{L}(360 \mu \mathrm{g} / \mathrm{L}) \mathrm{GBH}$ increases ${ }^{45} \mathrm{Ca}^{2+}$ influx, while other concentrations tested did not alter basal calcium influx. The subsequent "in vitro" experiment was performed with $360 \mu \mathrm{g} / \mathrm{L} \mathrm{GBH}$, a concentration lower than that reported as Brazilian limits for glyphosate in drinking water. In accordance with Brazilian Resolution 274/2005 (ANVISA/MS 2005), which establishes the minimum quality characteristics that water for human consumption must comply, the limit residue for glyphosate in drinking water is $500 \mu \mathrm{g} / \mathrm{L}$. Therefore, we must suggest that the lower limit for glyphosate in water needs be reviewed. Figure $1 \mathrm{C}$ showed that the glyphosate-induced calcium influx was prevented by U73122, LY294002, nifedipine and by the antioxidant NAC, demonstrating the involvement of PLC, PI3K/Akt, L-type VDCC and oxidative events, respectively, in the hepatotoxic effect of the herbicide.

\subsection{Oxidative status in the liver of immature rats perinatally exposed to $\mathrm{GBH}$}


The protective effect of NAC on GBH-induced ${ }^{45} \mathrm{Ca}^{2+}$ influx suggests that the redox status is involved in mechanism of hepatotoxicity of glyphosate. Thus, some biomarkers of oxidative damage were measured to evaluate the effects of perinatal GBH exposure on the liver of immature pups. Results showed that perinatal exposure to GBH increased the ROS-sensitive fluorescence of $\mathrm{H}_{2}$ DCFDA, suggesting a pesticideinduced ROS production (Fig. 2A). Perinatal exposure to GBH also evokes lipid peroxidation (Fig. 2B) and increased protein carbonyl levels (Fig. $2 \mathrm{C}$ ) in the immature rat liver, indicating a pesticide-induced oxidative damage to lipids and proteins. The involvement of redox imbalance in the hepatotoxic effects of GBH was also supported by GSH depletion in the liver of the pesticide-exposed pups (Fig. 2D).

Once established that perinatal exposure to GBH leads to oxidative stress, we investigated the activity of enzymatic antioxidant defense systems in offspring's liver. Results showed that GBH exposure downregulated G6PD and SOD in offspring's liver (Fig. 3A and 3E). Conversely, GR, GST and CAT activities were increased (Fig. 3B, 3D and 3F), while GPx activity was unaltered by the perinatal exposure to herbicide (Fig. 3C).

\subsection{Effects of perinatal GBH exposure on biomarkers of hepatic function}

The activities of ALT, AST and GGT within the liver and in serum from GBH-exposed pups were determined as biochemical parameters of liver function (tissue activity) and injury (serum activity). Perinatal GBH exposure increased both tissue and serum activities of all enzymes investigated (Fig. 4). The increased activity of AST, ALT and GGT observed in the serum of GBH exposed pups indicates liver injury by the releasing of the enzymes from hepatic tissue to blood.

\subsection{Effects of perinatal GBH-exposure on iron homeostasis of 15-days-old rats}

Iron accumulation is common to several pathological conditions and the liver is regarded as the main site of iron toxicity and overload (Pietrangelo 2016). The results showed increased levels of iron both in serum and in liver of GBH exposed rats (Fig. 5A), which were accompanied by decreased serum levels of transferrin (Fig. 5B). The iron accumulation induced by glyphosate-exposure was also attested by increased TIBC and transferrin saturation in blood of perinatal exposed pups (Fig. 5C and 5D, respectively). These results are compatible with iron overload and liver injury. The increased TIBC, associated with increased transferrin saturation, suggests decreased transferrin availability to bind to iron, meaning that the available iron-binding capacity on transferrin is impaired, reinforcing the hypothesis that perinatal GBH exposure provoked iron overload.

To attest that GBH causes iron accumulation in pups, we performed Perls' Prussian blue staining of bone marrow. Representative images of bone marrow slides from control and GBH-exposed group are shown in Fig. 6. The results revealed increased number of eosinophils in the bone marrow of all exposed animals (Fig. 6E) and Fig. 6F presented iron deposits in the bone marrow of GBH-exposed pups. These results corroborate the data showing iron accumulation in blood and in liver of herbicide-treated rats (see Fig. 5). 


\subsection{Effects of perinatal GBH-exposure on hematological parameters of 15-days-old rats}

Iron accumulation induced by perinatal GBH exposure affects pup's erythrocyte profile, as demonstrated in Table 2, which showed increased red blood cell (RBC) number, hemoglobin ( $\mathrm{Hb}$ ) levels, hematocrit $(\mathrm{Ht})$, mean corpuscular volume (MCV) and mean corpuscular hemoglobin $(\mathrm{MCH})$, corroborating the increased amount of iron observed in blood, liver and bone marrow of treated pups (see Figs. 5 and 6).

Table 2

Erythrocyte profile of 15-day-old rats exposed to GBH during perinatal period.

\begin{tabular}{|c|c|c|}
\hline Parameters & Control & GBH \\
\hline $\operatorname{RBC}\left(10^{6} / \mathrm{uL}\right)$ & $3,27 \pm 0,07$ & $3,98 \pm 0,06 * \star \star$ \\
\hline $\mathrm{Hb}(\mathrm{g} / \mathrm{dL})$ & $6,8 \pm 0,2$ & $9,2 \pm 0,1^{\star \star \star}$ \\
\hline $\mathrm{Ht}(\%)$ & $20,9 \pm 0,5$ & $28,1 \pm 0,3^{\star \star \star}$ \\
\hline MCV (fL) & $63,8 \pm 0,7$ & $70,6 \pm 0,3^{\star \star *}$ \\
\hline $\mathrm{MCH}(\mathrm{pg})$ & $20,71 \pm 0,36$ & $23,1 \pm 0,01^{\star \star \star}$ \\
\hline $\mathrm{MCHC}(\mathrm{g} / \mathrm{dL})$ & $32,43 \pm 0,23$ & $32,69 \pm 0,06$ \\
\hline \multicolumn{3}{|c|}{ 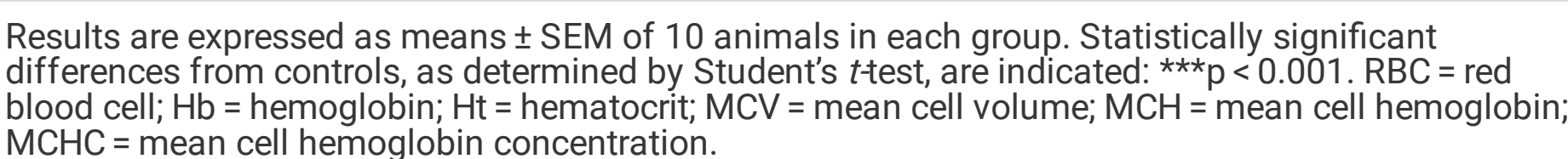 } \\
\hline
\end{tabular}

\subsection{Effect of perinatal exposure to GBH on cytokine levels and NF-kB activation in liver of 15-days-old-rats}

Perinatal exposure to GBH leads to oxidative stress and dysregulation of iron homeostasis, which may account for liver injury. Considering that inflammatory cytokines are key mediators of specific intracellular processes, such as survival and death, in response to liver injury, we verified the levels of proinflammatory cytokines IL- 6 and TNF-alfa in the liver of immature rats. Figure 7 shows increased levels of IL-6 and TNF-alfa in the liver of GBH-exposed rats (Fig. 7A and 7B). Since the pro-inflammatory cytokines modulate the nuclear factor-kB (NF-kB), we also investigated the involvement of this downstream signal in the mechanism of glyphosate-induced hepatotoxicity. Figure $7 \mathrm{C}$ demonstrated that perinatal GBH exposure increased the phosphorylation of p65-NF-KB. These results indicate the activation of pathways involved in inflammatory process in the liver of rats perinatally exposed to $\mathrm{GBH}$.

\section{Discussion}


In the present study, we investigated the hepatotoxic effects of perinatal exposure to GBH in offspring's liver, blood and bone marrow of immature rats. We demonstrated that perinatal exposure to GBH leads to calcium influx, oxidative stress, inflammation and iron overload culminating in hepatotoxicity.

We have previously demonstrated that perinatal exposure to GBH decreased the pup's body weight with no change in daily consumption of water and food, as well as the body weight of mothers (Cattani et al. 2014). Corroborating our previous findings, the present study also demonstrated that perinatal exposure to GBH impaired the growth and body weight gain of pups, emphasizing the potential impact of perinatal exposure to glyphosate on animal physiological growth.

Calcium-mediated signaling events are associated with cell physiology and toxic events. Our research group demonstrated that modulation of $\mathrm{Ca}^{2+}$ influx is related to the mechanism of action/toxicity of hormones, natural compounds, pesticides, alcohol and environmental pollutants in different tissues and cell types (Cattani et al. 2013; Cattani et al. 2014; Cesconetto et al. 2016; Domingues et al. 2018; Zamoner et al. 2007; Staldoni de Oliveira et al. 2021; Naspolini et al. 2021). In the present study, results showed that glyphosate-induced ${ }^{45} \mathrm{Ca}^{2+}$ influx is mediated by voltage-gated channels, through mechanisms involving PI3K/Akt and PLC signaling pathways as well as disruption in oxidative status, since NAC prevented GBH-induced calcium influx. In line with our results, recent studies also have shown that NAC can ameliorate most of the adverse effects against glyphosate-induced hepatotoxicity (Hashim et al. 2021; Turkmen et al. 2019). Therefore, we propose that GBH-exposure leads to overstimulation of voltagegated channels increasing $\mathrm{Ca}^{2+}$ ionic flow into cells, triggering mitochondrial dysfunction, oxidative damage and inflammation.

Liver is particularly susceptible to toxicity since it plays a central role in the transformation and degradation of endogenous and exogenous chemicals. In order to maintain liver homeostasis, specific intracellular processes are initiated where the inflammatory cytokines, such as IL-6 and TNF-a, plays a pivotal role (Tacke, Luedde, and Trautwein 2009). In addition to their role as inflammatory cytokines, TNFa also mediates caspase-independent death via ROS formation (Malhi and Gores 2008) while IL-6 signaling may play an important role in protection from ROS-induced apoptosis (Taub 2003). Our data demonstrated that GBH-induced hepatotoxicity involves the production of the pro-inflammatory cytokines II- 6 and TNF-a, followed by the activation of NF-kB signaling pathway. A recent study showed that TNF-a and IL- 6 were upregulated in liver of adult male rats exposed to GBH (Pandey, Dhabade, and Kumarasamy 2019). Similar results were demonstrated for the pesticides fipronil and malathion, which induced liver injury through oxidative stress and NF-KB (RA et al. 2019; Lasram et al. 2014). NF-kB regulates important functions in liver physiology and pathology and may play a central role in the inflammatory response to cell injury (Dutta et al. 2006). It is also important for normal tissue development of various cell systems, including the liver (Papa et al. 2009).

The oxidative modification of enzymatic complexes of the respiratory chain, GSH depletion, lipid peroxidation and $\mathrm{Ca}^{2+}$ influx are the main events of mitochondrial peroxidative damage in hepatic cells (Zavodnik et al. 2013). Therefore, lipid peroxidation and protein oxidation reported in the present study 
might be a consequence of concomitant increase in ROS generation and depleted antioxidant defense systems in liver from $\mathrm{GBH}$-exposed pups.

Oxidative stress associated with $\mathrm{Ca}^{2+}$ influx were previously demonstrated as hallmarks of $\mathrm{GBH}$-induced neurotoxicity (Cattani et al. 2014; Cattani et al. 2017) and reproductive toxicity (de Liz Oliveira Cavalli et al. 2013). The $\mathrm{Ca}^{2+}$-mediated GBH hepatotoxicity was associated with the increase of GR, GST and CAT enzymatic activities, associated with downregulated G6PD and SOD activities. G6PD is the rate-limiting enzyme of the pentose phosphate pathway, which generates NADPH and ribose 5-phosphate. Thus, G6PD plays a key role in liver metabolism and in protecting cells against ROS, since NADPH is used as an electron donor to reduce glutathione in addition to reductive biosynthesis. Downregulated G6PD activity will be insufficient to restore NADPH/NADP ${ }^{+}$ratio and may cause the inability of the antioxidant system to detoxify ROS, leading to oxidative stress and activating pro-inflammatory signaling in glyphosateexposed rat liver. Similar results were demonstrated in diabetic rats ( $\mathrm{M}$ et al. 2006), where severe hyperglycemia decreased body weight and G6PD activity, and depleted glutathione levels in the rat liver. Downregulation of G6PD was also demonstrated by us as a hallmark of GBH-induced cell toxicity and oxidative damage in brain (Cattani et al. 2014; Cattani et al. 2017).

Our results clearly demonstrate a disruption in the homeostasis of GSH, the most abundant cellular nonprotein thiol antioxidant, which exhibits numerous and versatile functions protecting cells against hepatotoxicity (Chen et al. 2013). Through the GST family enzymes, GSH may be conjugated to a variety of endogenous compounds and to xenobiotics leading to their safe and efficient elimination (Halliwell and Gutteridge 2007). Thus, GSH depletion might be a consequence of its consumption by GST. Upon reaction with ROS, GSH becomes oxidized to GSSG, which can be reduced again by GR. Thus, the oxidative stress probably evokes an adaptive response leading to the modulation of the enzymatic activities of GR (to replenish GSH levels) and GST (to xenobiotic detoxification). Also, the increased activity of CAT may be involved in removing excess of hydrogen peroxide produced by GBH-induced hepatotoxicity. On the other hand, SOD downregulation might account for superoxide accumulation and subsequent cell damage.

Considering the role of liver in glutamate metabolism, here we hypothesized that abnormal glutamate metabolism might be involved in perinatal GBH-induced pup's liver injury. Perinatal exposure to GBH increased either hepatic or serum levels of AST and ALT, two enzymes described as sensitive blood indicators of liver damage or injury (loannou, Boyko, and Lee 2006). In the liver, AST and ALT may be involved in the energy metabolism providing oxaloacetate or alfa-ketoglutarate to tricarboxylic acid cycle and/or they might be participating in glutamate metabolism, which are essential for amino acid metabolism, allowing the liver to produce urea and excrete excess nitrogen (Erecińska and Silver 1990). Alanine aminotransferase catalyzes the reversible interconversion of pyruvate to alanine in muscle cells. Then, alanine is carried by the bloodstream to the liver and pyruvate is regenerated by transamination, providing an important substrate for gluconeogenesis. Thus, transaminases also participate in glucosealanine cycle, which transports nitrogen in a non-toxic form from peripheral tissues to the liver. 
Transaminases, therefore, play a key role in maintaining cell homeostasis, since they work in a variety of settings.

Circulating levels of AST or ALT (or both) are elevated in most hepatic diseases, and the degree of aminotransferase activity found in plasma roughly reflects the current activity of the disease process (Cecil, Goldman, and Schafer 2012). Therefore, increased activity of AST and ALT induced by GBH exposure in tissue supports the effect of the pesticide on liver metabolism, while increased activity of these enzymes in the serum suggests liver injury, which are releasing the enzymes from tissue to blood.

Corroborating the hepatotoxicity induced by perinatal exposure to the GBH, the activity of GGT was increased both in pup's liver and serum. GGT is primarily involved in metabolizing extracellular GSH, providing precursor amino acids to be assimilated and reutilized for intracellular GSH synthesis, protein synthesis or energy metabolism (Koenig and Seneff 2015). Health conditions that increase serum GGT levels might lead to increased free radical production and GSH depletion (Whitfield 2001). Moreover, it has been proposed that the GGT's predictive utility applies well beyond liver disease (Koenig and Seneff 2015).

Chronic liver diseases may be associated with iron-loading, contributing to the progression of the underlying disease to cirrhosis and hemochromatosis through iron-driven oxidative stress (Pietrangelo 2016). In iron overload states, the iron level will be high, particularly in the liver where iron is normally stored, and the transferrin level will be low or normal, leading to increased transferrin saturation (Rombout-Sestrienkova, van Kraaij, and Koek 2016). Our results demonstrated iron overload in serum, liver and bone marrow of GBH exposed pups, which were associated with decreased transferrin levels and increased transferrin saturation. The iron accumulation in GBH perinatally-exposed pups was attested by Perls' Prussian blue staining of bone marrow slides.

The hematological parameters of 15-days-old rats showed increased RBC number, $\mathrm{Hb}$ levels, $\mathrm{Ht}$, MCV and $\mathrm{MCH}$, corroborating the increased amount of iron observed in blood, liver and bone marrow of GBHexposed group. This increase in erythropoiesis may related to iron overload observed in the blood of GBHexposed group since most circulating iron is needed to fulfill heme synthesis during RBC production. Moreover, the increase in RBC number can provoke the iron deposits in the bone marrow as iron supply to this tissue comes under particular strain after conditions that trigger erythropoiesis (Kautz and Nemeth 2014).

Over the past decade, the essential contributions of GSH to cellular iron metabolism have come into focus. Studies have shown GSH as an important player in all aspects of iron metabolism by regulating iron levels and trafficking, and biosynthesis of iron cofactors (Berndt and Lillig 2017; Daniel et al. 2020). Thus, decreased GSH content may be involved, at least in part, in the iron overload observed in the GBHexposed group. Excessive amounts of iron can be toxic and can lead to the progressive accumulation of iron compounds in organs and tissues, which may eventually cause their dysfunction and failure $(Y, E$, and $F$ 2017; P et al. 2019). 
The accumulation of "free" non-protein-bound iron in blood and tissues may initiate cell injury and cause hepatotoxicity due to iron-induced free radical formation mainly through the formation of reactive hydroxyl radicals by the Fenton reaction. The overproduction of free radicals might induce oxidative stress (Afanas'ev 2005). Therefore, organs that have high oxidative metabolism, as liver, are the most susceptible to ROS-induced damage (Wessling-Resnick 2017).

The oxidative stress caused by perinatal exposure to GBH in rat liver, associated with iron accumulation, may induce early epigenetic changes that could lead to adverse outcomes later in life. Indeed, the neonatal period is critical for the establishment of normal iron content in the adult brain (Fredriksson et al. 2000) and animals' studies have indicated that high iron exposure during a critical postnatal period promotes neuronal damage that affects cognition and memory and induces neurobehavioral dysfunctions and neurotoxicity (Wessling-Resnick 2017; Fredriksson et al. 2000; Fredriksson and Archer 2003; de Lima et al. 2007). In rats, the rate of iron uptake by the brain are maximal over the first 15 days of life (Taylor and Morgan 1990). Interestingly, we previously shown that the perinatal exposure to GBH induced neurotoxicity in 15-days-old rats, which was associated with depressive-like behavior later in life (Cattani et al. 2017; Cattani et al. 2014). Therefore, we suggest that the neurotoxic effects previously reported by us may be connected to the iron accumulation demonstrated in the present study. However, whether iron overload and developmental neurotoxicity after GBH-exposure are linked needs to be further evaluated.

The proposed mechanism of GBH-induced hepatoxicity involves $\mathrm{Ca}^{2+}$ influx, iron overload, inflammation and oxidative stress (Fig. 8). The disruption on calcium and iron homeostasis may compromise the liver's antioxidant defense system leading to GSH depletion, lipid peroxidation, protein carbonylation and inflammation leading to hepatotoxicity. In addition, the glutamate metabolism was altered in the liver of GBH-exposed pups. Determination of iron levels, transferrin saturation, GGT, ALT and AST in blood samples were demonstrated as peripheral biomarkers of GBH-induced liver injury. Taken together, our results suggest a potential risk for oxidative injury of the liver from immature pups exposed to GBH during fetal and post-natal early life.

\section{Declarations}

\section{Declaration of Interest}

Authors declare that there is no conflict of interest that could be perceived as prejudicing the impartiality of the research reported.

\section{Authors Contribution}

All authors contributed to the study conception and design. Material preparation, data collection and analysis were performed by Ariane Zamoner, Carla Elise Heinz Rieg, Daiane Cattani, Vitoria Hayduck Cenci, Nathalia Ferrazzo Naspolini, Vera Lúcia de Liz Oliveira Cavalli and Amanda Virtuoso Jacques. The 
manuscript was written by Ariane Zamoner and revised by Daiane Cattani and Ariane Zamoner. All authors read and approved the final manuscript.

\section{Funding}

This work was supported by grants from chamada pública FAPESC/MS-DECIT/CNPq/SES-SC - apoio a programa de pesquisa para o SUS - PPSUS (FAPESC/PPSUS; TO\#2017TR1365); Conselho Nacional de Desenvolvimento Científico e Tecnológico (CNPq-Brazil \#433245/2018-2 and \#309879/2017-5); and Coordenação de Aperfeiçoamento de Pessoal de Nível Superior (CAPES-Brazil).

\section{Acknowledgements}

We acknowledge FAPESC, DECIT/CNPq/SES-SC, PPSUS, CNPq-Brazil, CAPES, PGFAR and PPGBQA for grants and research scholarships. Carla Elise Heinz Rieg was registered on Pharmacy Graduate Course/UFSC-Brazil (PGFAR) and Vitoria Hayduck Cenci on Biochemistry Graduate Course/UFSC-Brazil. We also thank the assistance of the staff from the Multiuser Laboratory for Studies in Biology (LAMEB), linked to the Center for Biological Sciences (CCB) of the Federal University of Santa Catarina (UFSC).

\section{References}

1. Aebi, H. 1984. "Catalase in vitro." Methods Enzymo/ 105:121-6.

2. Afanas'ev, I. B. 2005. "Superoxide and nitric oxide in pathological conditions associated with iron overload: the effects of antioxidants and chelators." Curr Med Chem 12 (23):2731-9. doi: 10.2174/092986705774462941.

3. ANVISA/MS. 2005. RESOLUÇÃO № 274, DE 22 DE SETEMBRO DE 2005, da Agência Nacional de Vigilância Sanitária, Ministério da Saúde. Sistema de Legislação da Saúde.

4. Benbrook, Charles M. 2016. "Trends in glyphosate herbicide use in the United States and globally." Environmental Sciences Europe 28 (3):15. doi: 10.1186/s12302-016-0070-0.

5. Berndt, C., and C. H. Lillig. 2017. "Glutathione, Glutaredoxins, and Iron." Antioxid Redox Signal 27 (15):1235-1251. doi: 10.1089/ars.2017.7132.

6. BEUTLER, E., O. DURON, and B. M. KELLY. 1963. "Improved method for the determination of blood glutathione." J Lab Clin Med 61:882-8.

7. Bird, R. P., and H. H. Draper. 1984. "Comparative studies on different methods of malonaldehyde determination." Methods Enzymol 105:299-305.

8. Boveris, A., C. G. Fraga, A. I. Varsavsky, and O. R. Koch. 1983. "Increased chemiluminescence and superoxide production in the liver of chronically ethanol-treated rats." Arch Biochem Biophys 227 (2):534-41.

9. Carlberg, I., and B. Mannervik. 1985. "Glutathione reductase." Methods Enzymo/ 113:484-90.

10. Cassault-Meyer, E., S. Gress, G. E. Seralini, and I. Galeraud-Denis. 2014. "An acute exposure to glyphosate-based herbicide alters aromatase levels in testis and sperm nuclear quality." Environ 
Toxicol Pharmaco/ 38 (1):131-40. doi: 10.1016/j.etap.2014.05.007.

11. Cattani, D., P. A. Cesconetto, M. K. Tavares, E. B. Parisotto, P. A. De Oliveira, C. E. H. Rieg, M. C. Leite, R. D. S. Prediger, N. C. Wendt, G. Razzera, D. W. Filho, and A. Zamoner. 2017. "Developmental exposure to glyphosate-based herbicide and depressive-like behavior in adult offspring: Implication of glutamate excitotoxicity and oxidative stress." Toxicology 387:67-80. doi:

10.1016/j.tox.2017.06.001.

12. Cattani, D., V. L. de Liz Oliveira Cavalli, C. E. Heinz Rieg, J. T. Domingues, T. Dal-Cim, C. I. Tasca, F. R. Mena Barreto Silva, and A. Zamoner. 2014. "Mechanisms underlying the neurotoxicity induced by glyphosate-based herbicide in immature rat hippocampus: involvement of glutamate excitotoxicity." Toxicology 320:34-45. doi: 10.1016/j.tox.2014.03.001.

13. Cattani, D., P. B. Goulart, V. L. Cavalli, E. Winkelmann-Duarte, A. Q. Dos Santos, P. Pierozan, D. F. de Souza, V. M. Woehl, M. C. Fernandes, F. R. Silva, C. A. Goncalves, R. Pessoa-Pureur, and A. Zamoner. 2013. "Congenital hypothyroidism alters the oxidative status, enzyme activities and morphological parameters in the hippocampus of developing rats." Mol Cell Endocrinol 375 (1-2):14-26. doi: 10.1016/j.mce.2013.05.001.

14. Cecil, Russell L., Lee Goldman, and Andrew I. Schafer. 2012. Goldman's Cecil medicine. 24th ed. 2 vols. Philadelphia, PA: Elsevier/Saunders.

15. Cesconetto, P. A., C. M. Andrade, D. Cattani, J. T. Domingues, E. B. Parisotto, D. W. Filho, and A. Zamoner. 2016. "Maternal Exposure to Ethanol During Pregnancy and Lactation Affects Glutamatergic System and Induces Oxidative Stress in Offspring Hippocampus." Alcohol Clin Exp Res 40 (1):52-61. doi: 10.1111/acer.12917.

16. Chen, Y., H. Dong, D. Thompson, H. Shertzer, D. Nebert, and V. Vasiliou. 2013. "GLUTATHIONE DEFENSE MECHANISM IN LIVER INJURY: INSIGHTS FROM ANIMAL MODELS." Food Chem Toxicol 60:38-44. doi: 10.1016/j.fct.2013.07.008.

17. Dacie, JV, and SM Lewis. 1995. Practical Haematology. New York: Churchill Livingstone.

18. Daniel, T., H. M. Faruq, J. Laura Magdalena, G. Manuela, and L. Christopher Horst. 2020. "Role of GSH and Iron-Sulfur Glutaredoxins in Iron Metabolism-Review." Molecules 25 (17). doi: 10.3390/molecules25173860.

19. de Lima, M. N., J. Presti-Torres, F. Caldana, M. M. Grazziotin, F. S. Scalco, M. R. Guimarães, E. Bromberg, S. I. Franke, J. A. Henriques, and N. Schröder. 2007. "Desferoxamine reverses neonatal iron-induced recognition memory impairment in rats." Eur J Pharmaco/ 570 (1-3):111-4. doi: 10.1016/j.ejphar.2007.06.002.

20. de Liz Oliveira Cavalli, Vera Lucia, Daiane Cattani, Carla Elise Heinz Rieg, Paula Pierozan, Leila Zanatta, Eduardo Benedetti Parisotto, Danilo Wilhelm Filho, Fatima Regina Mena Barreto Silva, Regina Pessoa-Pureur, and Ariane Zamoner. 2013. "Roundup disrupts male reproductive functions by triggering calcium-mediated cell death in rat testis and Sertoli cells." Free Radical Biology and Medicine 65:335-346. doi: 10.1016/j.freeradbiomed.2013.06.043. 
21. Domingues, J. T., D. Cattani, P. A. Cesconetto, B. A. Nascimento de Almeida, P. Pierozan, K. Dos Santos, G. Razzera, F. R. Mena Barreto Silva, R. Pessoa-Pureur, and A. Zamoner. 2018. "Reverse T3 interacts with alphavbeta3 integrin receptor and restores enzyme activities in the hippocampus of hypothyroid developing rats: Insight on signaling mechanisms." Mol Cell Endocrinol 470:281-294. doi: 10.1016/j.mce.2017.11.013.

22. Dutta, J., Y. Fan, N. Gupta, G. Fan, and C. Gélinas. 2006. "Current insights into the regulation of programmed cell death by NF-KB." Oncogene 25 (51):6800-6816. doi: 10.1038/sj.onc.1209938.

23. Erecińska, M., and I. A. Silver. 1990. "Metabolism and role of glutamate in mammalian brain." Prog Neurobiol 35 (4):245-96.

24. Flohé, L., and W. A. Günzler. 1984. "Assays of glutathione peroxidase." Methods Enzymo/105:11421.

25. Fredriksson, A., and T. Archer. 2003. "Effect of postnatal iron administration on MPTP-induced behavioral deficits and neurotoxicity: behavioral enhancement by L-Dopa-MK-801 co-administration." Behav Brain Res 139 (1-2):31-46. doi: 10.1016/s0166-4328(02)00035-9.

26. Fredriksson, A., N. Schröder, P. Eriksson, I. Izquierdo, and T. Archer. 2000. "Maze learning and motor activity deficits in adult mice induced by iron exposure during a critical postnatal period." Brain Res Dev Brain Res 119 (1):65-74. doi: 10.1016/s0165-3806(99)00160-1.

27. Goodwin, J. F., B. Murphy, and M. Guillemette. 1966. "Direct measurement of serum iron and binding capacity." Clin Chem 12 (2):47-57.

28. Guyton, K. Z., D. Loomis, Y. Grosse, F. El Ghissassi, L. Benbrahim-Tallaa, N. Guha, C. Scoccianti, H. Mattock, K. Straif, and I. A. R.C International Agency for Research on Cancer Monograph Working Group, Lyon, F.ance. 2015. "Carcinogenicity of tetrachlorvinphos, parathion, malathion, diazinon, and glyphosate." Lancet Oncol 16 (5):490-1. doi: 10.1016/S1470-2045(15)70134-8.

29. Habig, W. H., M. J. Pabst, and W. B. Jakoby. 1974. "Glutathione S-transferases. The first enzymatic step in mercapturic acid formation." J Biol Chem 249 (22):7130-9.

30. Halliwell, B., and M. Whiteman. 2004. "Measuring reactive species and oxidative damage in vivo and in cell culture: how should you do it and what do the results mean?" Br J Pharmacol 142 (2):231-55. doi: $10.1038 /$ sj.bjp.0705776.

31. Halliwell, Barry, and John M. C. Gutteridge. 2007. Free Radicals in Biology and Medicine: Oxford University Press.

32. Hashim, A. R., D. W. Bashir, N. A. E. Yasin, M. K. Galal, and E. S. M. 2021. "Ameliorative effect of Nacetylcysteine against glyphosate-induced hepatotoxicity in adult male albino rats: histopathological, biochemical, and molecular studies." Environ Sci Pollut Res Int. doi: 10.1007/s11356-021-13659-2.

33. IARC. 2015. IARC Monographs on the Evaluation of Carcinogenic Risks to Humans - Glyphosate monograph. edited by International Agency for Research on Cancer: World Health Organization.

34. IBAMA. 2014. Boletim de Comercialização de Agrotóxicos e Afins - Histórico de Vendas 2000-2012. edited by Diretoria de Qualidade Ambiental - DIQUA. Brasília, DF: Ministério do Meio Ambiente - 
MMA.

35. IBAMA. 2019. Instituto Brasileiro do Meio Ambiente e dos Recursos Naturais Renováveis (IBAMA). Histórico de comercialização de semioquímicos e microbiológicos 2014 - 2019. IBAMA / Consolidação de dados fornecidos pelas empresas registrantes de produtos técnicos, agrotóxicos e afins, conforme art. 41 do Decreto $n^{\circ} 4.074 / 2002$.

36. Ioannou, G. N., E. J. Boyko, and S. P. Lee. 2006. "The prevalence and predictors of elevated serum aminotransferase activity in the United States in 1999-2002." Am J Gastroenterol 101 (1):76-82. doi: 10.1111/j.1572-0241.2005.00341.x.

37. Kautz, L., and E. Nemeth. 2014. "Molecular liaisons between erythropoiesis and iron metabolism." Blood 124 (4):479-82. doi: 10.1182/blood-2014-05-516252.

38. Koenig, G., and S. Seneff. 2015. "Gamma-Glutamyltransferase: A Predictive Biomarker of Cellular Antioxidant Inadequacy and Disease Risk." Dis Markers 2015:818570. doi: 10.1155/2015/818570.

39. Kreutzer, H. J. 1976. "An immunological turbidimetric method for serum transferrin determination." $J$ Clin Chem Clin Biochem 14 (8):401-6.

40. Lasram, Mohamed Montassar, Ines Bini Dhouib, Kahna Bouzid, Aicha Jrad Lamine, Alya Annabi, Nadia Belhadjhmida, Malika Ben Ahmed, Saloua El Fazaa, Jaouida Abdelmoula, and Najoua Gharbi. 2014. "Association of inflammatory response and oxidative injury in the pathogenesis of liver steatosis and insulin resistance following subchronic exposure to malathion in rats." Environmental Toxicology and Pharmacology 38 (2):542-553. doi: https://doi.org/10.1016/j.etap.2014.08.007.

41. Levine, R. L., D. Garland, C. N. Oliver, A. Amici, I. Climent, A. G. Lenz, B. W. Ahn, S. Shaltiel, and E. R. Stadtman. 1990. "Determination of carbonyl content in oxidatively modified proteins." Methods Enzymol 186:464-78.

42. LOWRY, O. H., N. J. ROSEBROUGH, A. L. FARR, and R. J. RANDALL. 1951. "Protein measurement with the Folin phenol reagent." J Biol Chem 193 (1):265-75.

43. M, Díaz-Flores, Ibáñez-Hernández MA, Galván RE, Gutiérrez $M$, Durán-Reyes $G$, Medina-Navarro $R$, Pascoe-Lira D, Ortega-Camarillo C, Vilar-Rojas C, Cruz M, and Baiza-Gutman LA. 2006. "Glucose-6phosphate dehydrogenase activity and NADPH/NADP+ ratio in liver and pancreas are dependent on the severity of hyperglycemia in rat." Life sciences 78 (22). doi: 10.1016/j.Ifs.2005.10.022.

44. Malhi, Harmeet, and Gregory J. Gores. 2008. "Cellular and Molecular Mechanisms of Liver Injury." Gastroenterology 134 (6):1641-1654. doi: https://doi.org/10.1053/j.gastro.2008.03.002.

45. Mesnage, R., M. Arno, M. Costanzo, M. Malatesta, G. E. Seralini, and M. N. Antoniou. 2015. "Transcriptome profile analysis reflects rat liver and kidney damage following chronic ultra-low dose Roundup exposure." Environ Health 14:70. doi: 10.1186/s12940-015-0056-1.

46. Mesnage, R., G. Renney, G. E. Séralini, M. Ward, and M. N. Antoniou. 2017. "Multiomics reveal nonalcoholic fatty liver disease in rats following chronic exposure to an ultra-low dose of Roundup herbicide." Sci Rep 7:39328. doi: 10.1038/srep39328.

47. Milić, M., S. Žunec, V. Micek, V. Kašuba, A. Mikolić, B. T. Lovaković, TŽ Semren, I. Pavičić, A. M. M. Čermak, A. Pizent, A. L. Vrdoljak, R. Valencia-Quintana, J. Sánchez-Alarcón, and D. Želježić. 2018. 
"Oxidative stress, cholinesterase activity, and DNA damage in the liver, whole blood, and plasma of Wistar rats following a 28-day exposure to glyphosate." Arh Hig Rada Toksikol 69 (2):154-168. doi: 10.2478/aiht-2018-69-3114.

48. Misra, H. P., and I. Fridovich. 1972. "The role of superoxide anion in the autoxidation of epinephrine and a simple assay for superoxide dismutase." J Biol Chem 247 (10):3170-5.

49. Myers, J. P., M. N. Antoniou, B. Blumberg, L. Carroll, T. Colborn, L. G. Everett, M. Hansen, P. J. Landrigan, B. P. Lanphear, R. Mesnage, L. N. Vandenberg, F. S. Vom Saal, W. V. Welshons, and C. M. Benbrook. 2016. "Concerns over use of glyphosate-based herbicides and risks associated with exposures: a consensus statement." Environ Health 15:19. doi: 10.1186/s12940-016-0117-0.

50. Naspolini, N. F., C. E. Heinz Rieg, V. H. Cenci, D. Cattani, and A. Zamoner. 2021. "Paraquat induces redox imbalance and disrupts glutamate and energy metabolism in the hippocampus of prepubertal rats." Neurotoxicology 85:121-132. doi: 10.1016/j.neuro.2021.05.010.

51. ORLOWSKI, M., and A. MEISTER. 1963. "GAMMA-GLUTAMYL-P-NITROANILIDE: A NEW CONVENIENT SUBSTRATE FOR DETERMINATION AND STUDY OF L- AND D-GAMMAGLUTAMYLTRANSPEPTIDASE ACTIVITIES." Biochim Biophys Acta 73:679-81.

52. P, Brissot, Troadec MB, Loréal O, and Brissot E. 2019. "Pathophysiology and classification of iron overload diseases; update 2018." Transfusion clinique et biologique : journal de la Societe francaise de transfusion sanguine 26 (1). doi: 10.1016/j.tracli.2018.08.006.

53. Paganelli, A., V. Gnazzo, H. Acosta, S. L. López, and A. E. Carrasco. 2010. "Glyphosate-based herbicides produce teratogenic effects on vertebrates by impairing retinoic acid signaling." Chem Res Toxicol 23 (10):1586-95. doi: 10.1021/tx1001749.

54. Pandey, Aparamita, Prachi Dhabade, and Anand Kumarasamy. 2019. "Inflammatory Effects of Subacute Exposure of Roundup in Rat Liver and Adipose Tissue." Dose-response : a publication of International Hormesis Society 17 (2):1559325819843380-1559325819843380. doi: $10.1177 / 1559325819843380$.

55. Papa, S., C. Bubici, F. Zazzeroni, and G. Franzoso. 2009. "Mechanisms of liver disease: cross-talk between the NF-kappaB and JNK pathways." Biol Chem 390 (10):965-76. doi: 10.1515/bc.2009.111.

56. Persijn, J. P., W. van der Slik, and A. Riethorst. 1971. "Determination of serum iron and latent ironbinding capacity (LIBC)." Clin Chim Acta 35 (1):91-8.

57. Pietrangelo, A. 2016. "Iron and the liver." Liver Int 36 Suppl 1:116-23. doi: 10.1111/liv.13020.

58. Portier, C. J. 2020. "A comprehensive analysis of the animal carcinogenicity data for glyphosate from chronic exposure rodent carcinogenicity studies." Environ Health 19 (1):18. doi: 10.1186/s12940020-00574-1.

59. RA, Elgawish, Abdelrazek HMA, Ismail SAA, Loutfy NM, and Soliman MTA. 2019. "Hepatoprotective activity of Uncaria tomentosa extract against sub-chronic exposure to fipronil in male rats." Environmental science and pollution research international 26 (1). doi: 10.1007/s11356-018-3615-5.

60. REITMAN, S., and S. FRANKEL. 1957. "A colorimetric method for the determination of serum glutamic oxalacetic and glutamic pyruvic transaminases." Am J Clin Pathol 28 (1):56-63. 
61. Ren, X., P. Dai, A. Perveen, Q. Tang, L. Zhao, X. Jia, Y. Li, and C. Li. 2019. "Effects of chronic glyphosate exposure to pregnant mice on hepatic lipid metabolism in offspring." Environ Pollut 254 (Pt A):112906. doi: 10.1016/j.envpol.2019.07.074.

62. Romano, R. M., J. M. de Oliveira, V. M. de Oliveira, I. M. de Oliveira, Y. R. Torres, P. Bargi-Souza, A. J. Martino Andrade, and M. A. Romano. 2021. "Could Glyphosate and Glyphosate-Based Herbicides Be Associated With Increased Thyroid Diseases Worldwide?" Front Endocrinol (Lausanne) 12:627167. doi: 10.3389/fendo.2021.627167.

63. Rombout-Sestrienkova, E., M. G. van Kraaij, and G. H. Koek. 2016. "How we manage patients with hereditary haemochromatosis." Br J Haematol 175 (5):759-770. doi: 10.1111/bjh.14376.

64. Solem, E. 1984. "Glucose-6 phosphate dehydrogenase deficiency: an easy and sensitive quantitative assay for the detection of female heterozygotes in red blood cells." Clin Chim Acta 142 (2):153-60.

65. Soudani, N., M. Chaâbane, I. Ghorbel, A. Elwej, T. Boudawara, and N. Zeghal. 2019. "Glyphosate disrupts redox status and up-regulates metallothionein I and II genes expression in the liver of adult rats. Alleviation by quercetin." Gen Physiol Biophys 38 (2):123-134. doi: 10.4149/gpb_2018043.

66. Staldoni de Oliveira, V., A. J. Gomes Castro, K. Marins, A. K. Bittencourt Mendes, G. A. Araújo Leite, A. Zamoner, G. Van Der Kraak, and F. R. Mena Barreto Silva. 2021. "Pyriproxyfen induces intracellular calcium overload and alters antioxidant defenses in Danio rerio testis that may influence ongoing spermatogenesis." Environ Pollut 270:116055. doi: 10.1016/j.envpol.2020.116055.

67. Tacke, Frank, Tom Luedde, and Christian Trautwein. 2009. "Inflammatory Pathways in Liver Homeostasis and Liver Injury." Clinical Reviews in Allergy \& Immunology 36 (1):4-12. doi: 10.1007/s12016-008-8091-0.

68. Tang, Juan, Ping Hu, Yansen Li, Tin-Tin Win-Shwe, and Chunmei Li. 2017. "Ion Imbalance Is Involved in the Mechanisms of Liver Oxidative Damage in Rats Exposed to Glyphosate." Frontiers in physiology 8:1083-1083. doi: 10.3389/fphys.2017.01083.

69. Taub, R. 2003. "Hepatoprotection via the IL-6/Stat3 pathway." J Clin Invest 112 (7):978-80. doi: 10.1172/jci19974.

70. Taylor, E. M., and E. H. Morgan. 1990. "Developmental changes in transferrin and iron uptake by the brain in the rat." Brain Res Dev Brain Res 55 (1):35-42. doi: 10.1016/0165-3806(90)90103-6.

71. Tizhe, E. V., N. D. Ibrahim, M. Y. Fatihu, S. F. Ambali, I. O. Igbokwe, and U. D. Tizhe. 2020. "Effect of zinc supplementation on chronic hepatorenal toxicity following oral exposure to glyphosate-based herbicide (Bushfire®) in rats." J Int Med Res 48 (8):300060520925343. doi:

10.1177/0300060520925343.

72. Turkmen, R., Y. O. Birdane, H. H. Demirel, H. Yavuz, M. Kabu, and S. Ince. 2019. "Antioxidant and cytoprotective effects of $\mathrm{N}$-acetylcysteine against subchronic oral glyphosate-based herbicideinduced oxidative stress in rats." Environ Sci Pollut Res Int 26 (11):11427-11437. doi: 10.1007/s11356-019-04585-5.

73. Walsh, L. P., C. McCormick, C. Martin, and D. M. Stocco. 2000. "Roundup inhibits steroidogenesis by disrupting steroidogenic acute regulatory (StAR) protein expression." Environ Health Perspect 108 
(8):769-76.

74. Wessling-Resnick, Marianne. 2017. "Excess iron: considerations related to development and early growth." The American Journal of Clinical Nutrition 106 (suppl_6):1600S-1605S. doi: 10.3945/ajcn.117.155879.

75. Whitfield, J. B. 2001. "Gamma glutamyl transferase." Crit Rev Clin Lab Sci 38 (4):263-355. doi: $10.1080 / 20014091084227$.

76. Williams, G. M., R. Kroes, and I. C. Munro. 2000. "Safety evaluation and risk assessment of the herbicide Roundup and its active ingredient, glyphosate, for humans." Regul Toxicol Pharmacol 31 (2 Pt 1):117-65. doi: 10.1006/rtph.1999.1371.

77. Y, Deugnier, Bardou-Jacquet É, and Lainé F. 2017. "Dysmetabolic iron overload syndrome (DIOS)." Presse medicale (Paris, France : 1983) 46 (12 Pt 2). doi: 10.1016/j.lpm.2017.05.036.

78. Yee, H. Y., and A. Zin. 1971. "An autoanalyzer procedure for serum iron and total iron-binding capacity, with use of ferrozine." Clin Chem 17 (9):950-3.

79. Zamoner, Ariane, Carine Royer, Katia Padilha Barreto, Regina Pessoa-Pureur, and Fatima Regina Mena Barreto Silva. 2007. "Ionic involvement and kinase activity on the mechanism of nongenomic action of thyroid hormones on Ca-45(2+) uptake in cerebral cortex from young rats." Neuroscience Research 57 (1):98-103. doi: 10.1016/j.neures.2006.09.012.

80. Zavodnik, I. B., I. K. Dremza, V. T. Cheshchevik, E. A. Lapshina, and M. Zamaraewa. 2013. "Oxidative damage of rat liver mitochondria during exposure to t-butyl hydroperoxide. Role of $\mathrm{Ca}^{2} \rrbracket$ ions in oxidative processes." Life Sci 92 (23):1110-7. doi: 10.1016/j.Ifs.2013.04.009.

\section{Figures}



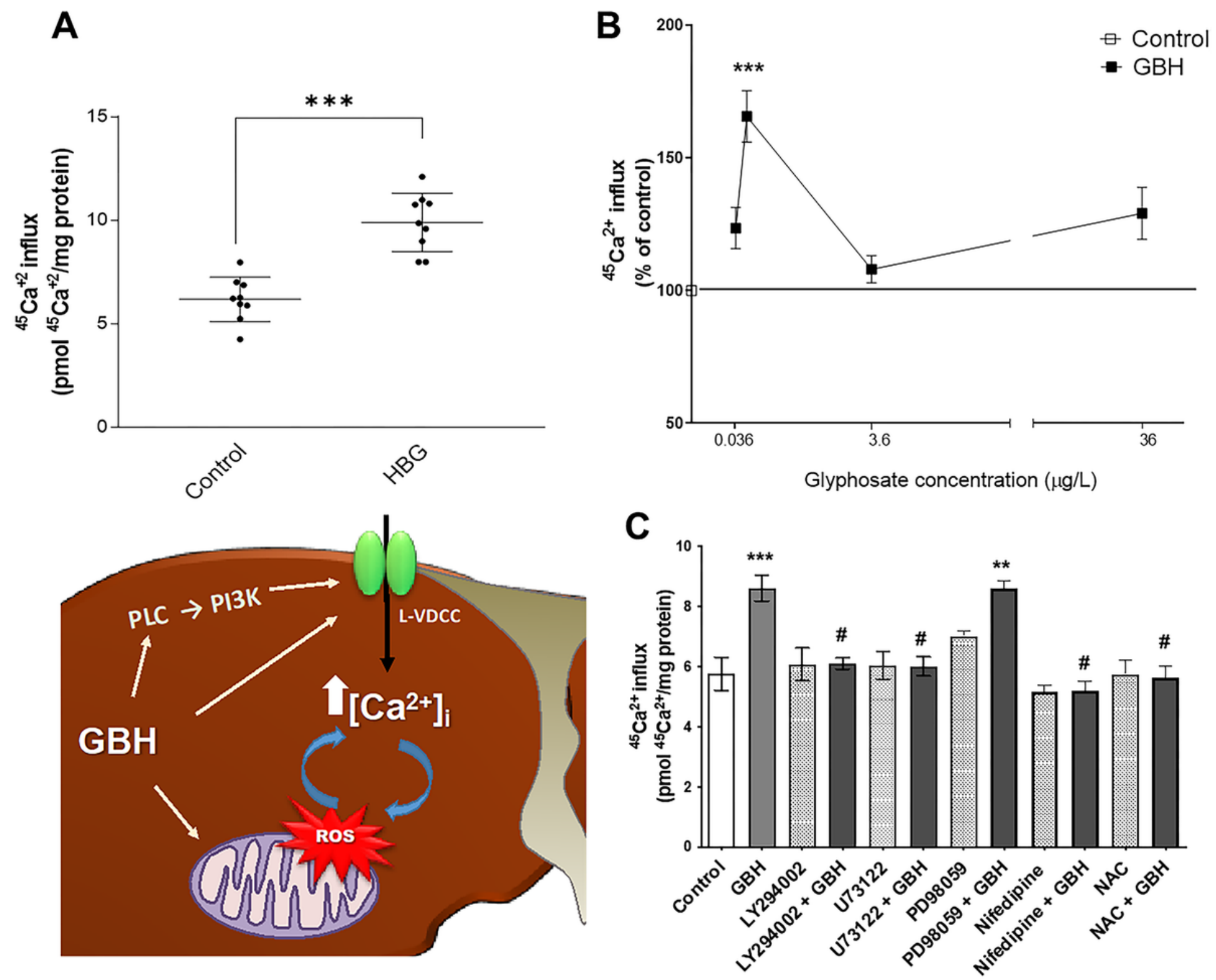

Figure 1

Effect of in vitro and in vivo exposure to $\mathrm{GBH}$ on $45 \mathrm{Ca} 2+$ influx in liver slices from 15-day-old offspring. (A) Liver slices from immature rats exposed or not to GBH during perinatal period were pre-incubated for $15 \mathrm{~min}$ and then incubated for $30 \mathrm{~min}$ with $0.1 \mathrm{mCi} / \mathrm{mL}$ of $45 \mathrm{Ca} 2$. (B) $\mathrm{GBH}$ at concentrations ranging from 0.036 to $36 \mathrm{mg} / \mathrm{L}$ was added to liver sliced of during the incubation period (in vitro GBH effects). (C) $10 \mu \mathrm{M}$ LY294002, $2 \mu \mathrm{M}$ U73122 (PLC inhibitor), $30 \mu \mathrm{M}$ PD 98059 (MAPK inhibitor), $10 \mu \mathrm{M}$ nifedipine (LVDCC blocker) or the antioxidant NAC were added during pre-incubation. After that, the slices were incubated with or without $0.36 \mathrm{mg} / \mathrm{L} \mathrm{GBH}$ for $30 \mathrm{~min}$ in the presence or absence of the drugs described above. The radioactivity incorporated into liver slices was measured and data are reported are means \pm S.E.M. of 8 animals in each group. Statistically significant difference from controls, as determined as determined by one-way ANOVA followed by Bonferroni multiple comparison test are indicated: ${ }^{* *} \mathrm{p}<$ 0.001 , ${ }^{\star \star *} \mathrm{p}<0.0001$ compared with control group; $\# \mathrm{p}<0.00 .1$ compared with GBH group. 

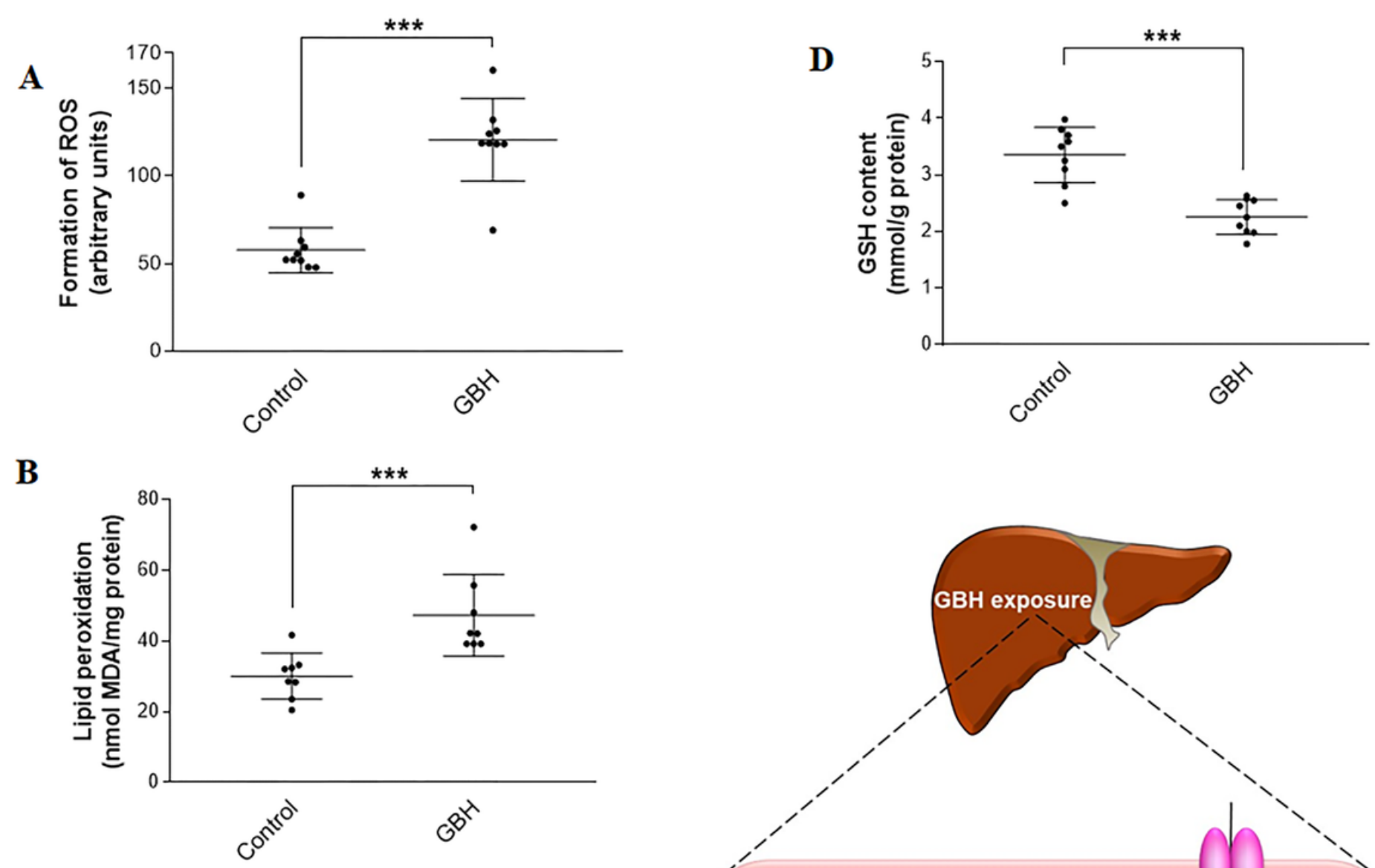

C
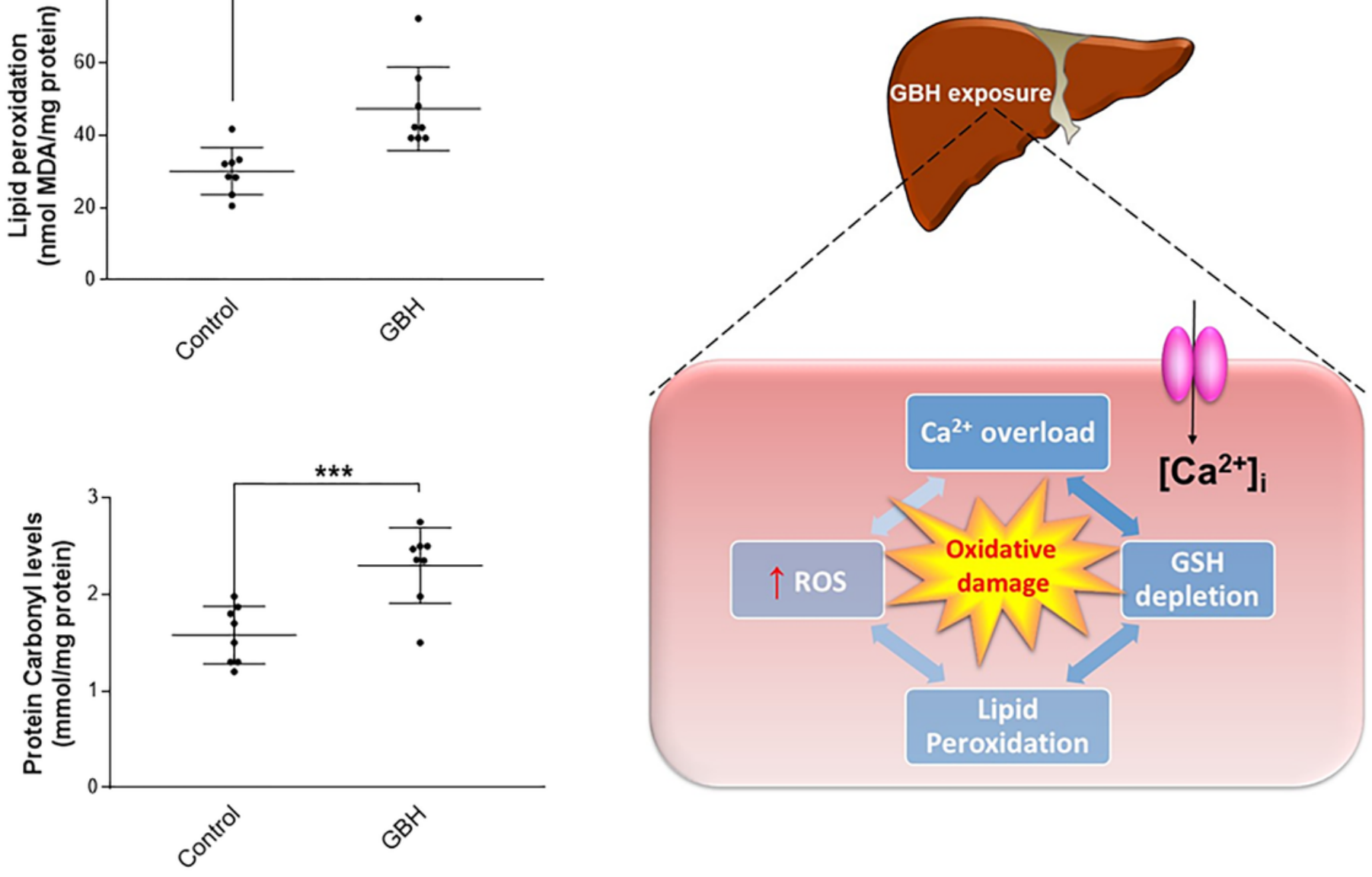

Figure 2

Effect of perinatal exposure to GBH on formation of ROS (A), lipid peroxidation (B), protein carbonyl levels (C) and on reduced glutathione (GSH) content (D) in offspring's liver. Data are reported as means \pm SEM of 8 animals in each group. Statistically significant difference from controls, as determined by Student's t-test are indicated: $* * * p<0.0001$. 
A

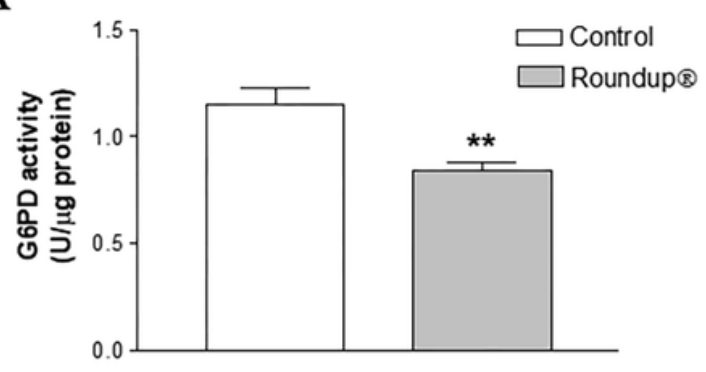

B

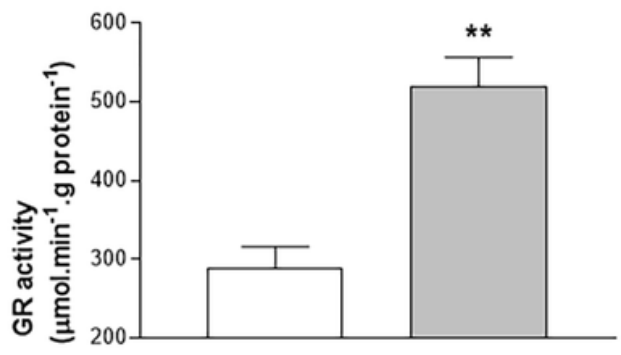

C

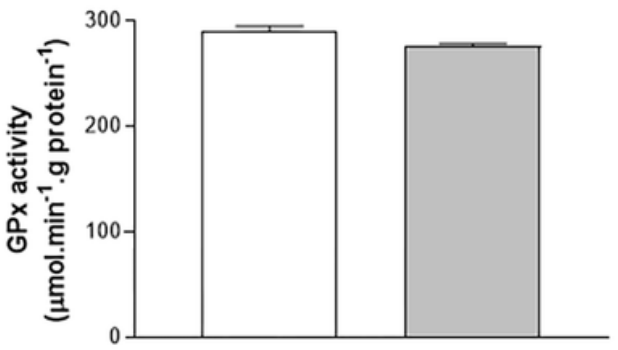

D

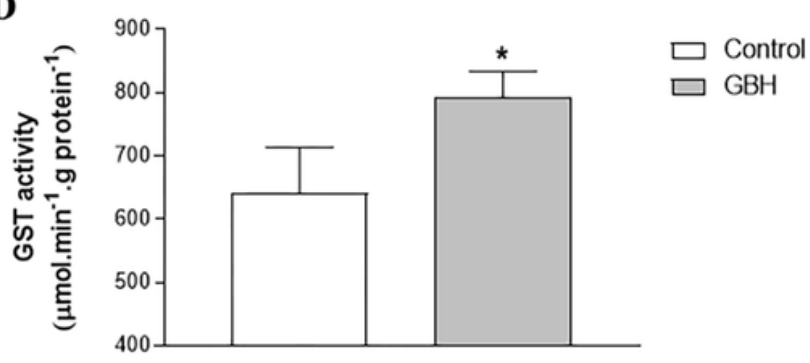

E
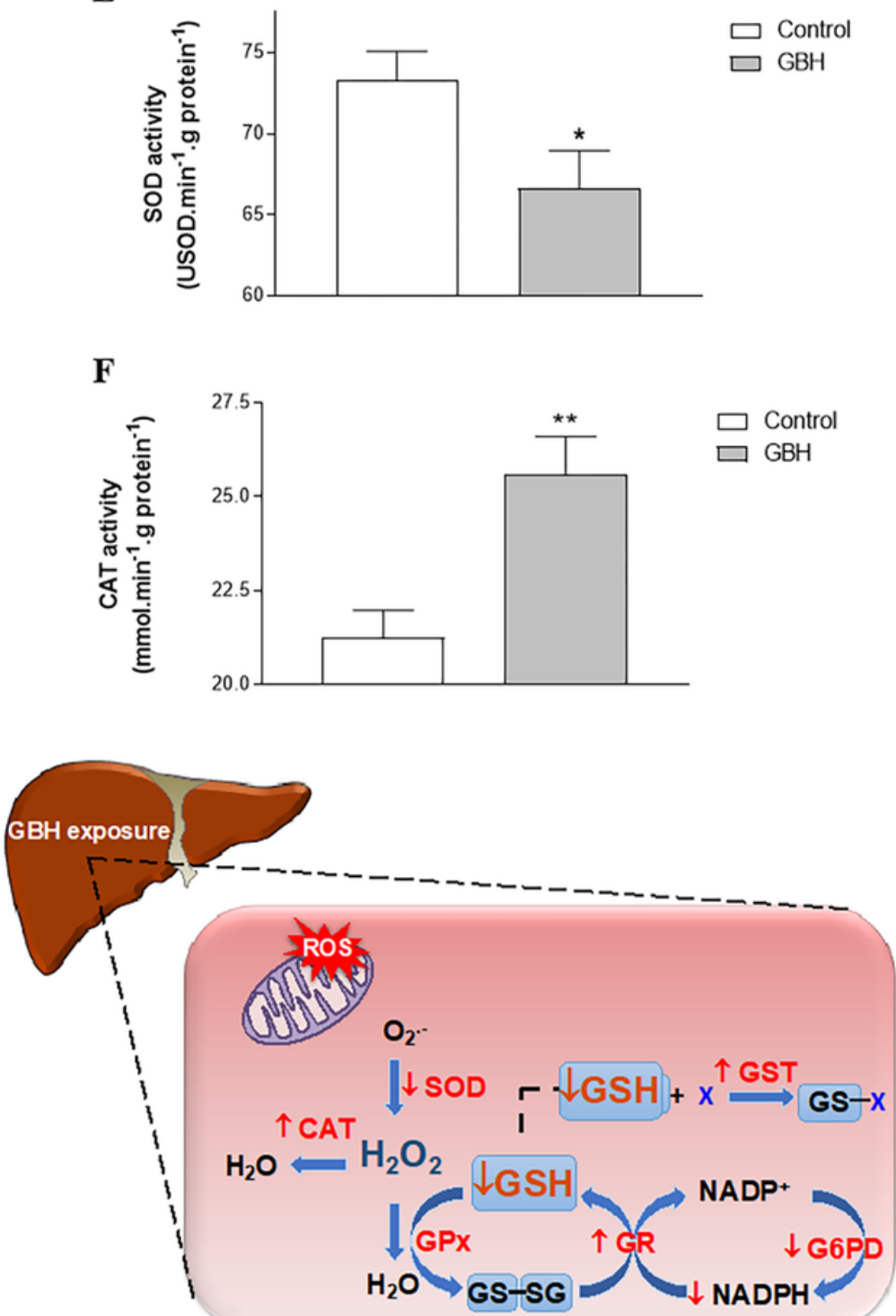

Figure 3

Effect of perinatal exposure to GBH during pregnancy and lactation on the activities of (A) glucose-6phosphate dehydrogenase (G6PD), (B) glutathione reductase (GR), (C) glutathione peroxidase (GPx), (D) glutathione S-transferase (GST), (E) superoxide dismutase (SOD), and (F) catalase (CAT) in immature rat liver. Data are reported as means \pm SEM of 8 animals in each group. Statistically significant difference from controls, as determined by Student's t-test are indicated: ${ }^{*} p<0.05,{ }^{* *} p<0.01$. 


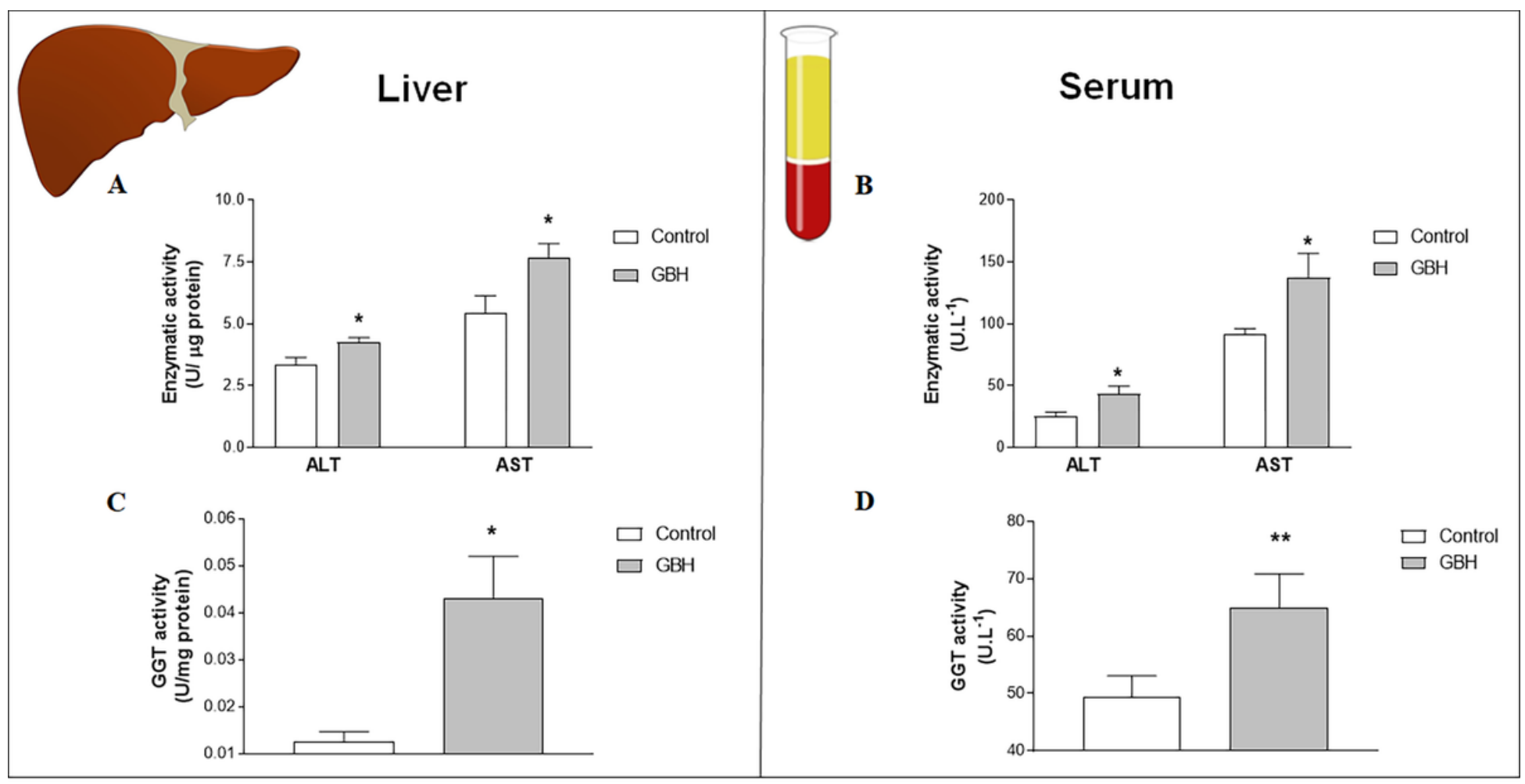

\section{Figure 4}

Effect of perinatal exposure to GBH on hepatic markers of liver injury in immature rat liver and serum.

Enzymatic activity of alanine aminostransferase (ALT) and aspartate aminotransferase (AST) (A), and $\gamma^{-}$ glutamyltransferase (GGT) (B) in rat liver from immature rats. Enzymatic activity of ALT and AST (C) and GGT (D) in serum from immature rats. Data are reported as means \pm SEM of 8 animals in each experimental group. Statistically significant difference from controls, as determined by Student's t-test are indicated: ${ }^{*} \mathrm{p}<0.01,{ }^{* *} \mathrm{p}<0.001$. 


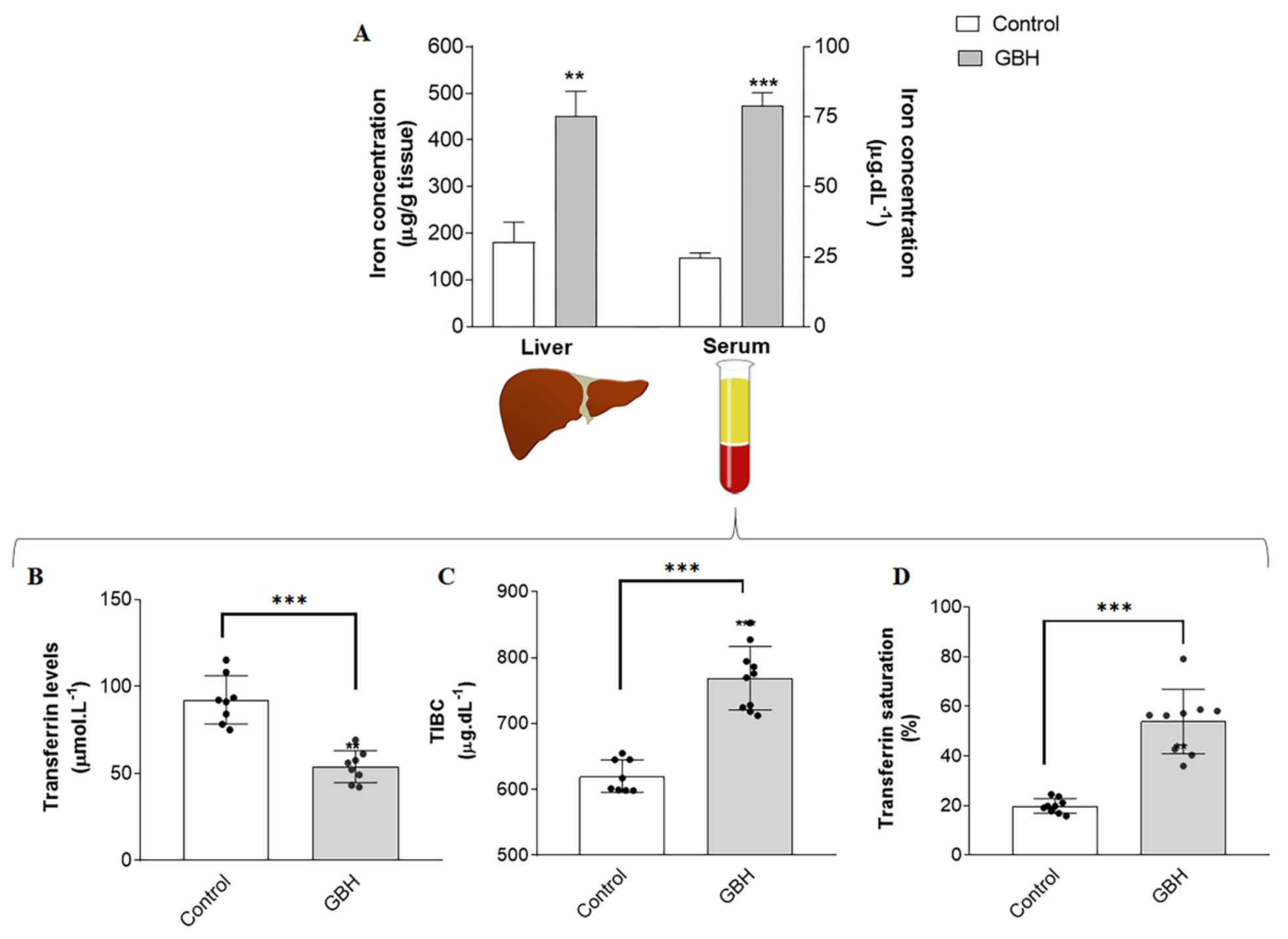

Figure 5

Effect of perinatal exposure to GBH on iron homeostasis in liver and serum of 15-days-old rats. Iron concentration in liver and serum(A); transferrin levels (B) and transferrin saturation (C) in serum of immature rats. Data are reported as means \pm SEM of 8 animals in each group. Statistically significant difference from controls, as determined by Student's t-test, are indicated: ${ }^{\star \star} p<0.001,{ }^{\star \star \star} p<0.0001$. 


\section{Celularity}

Control
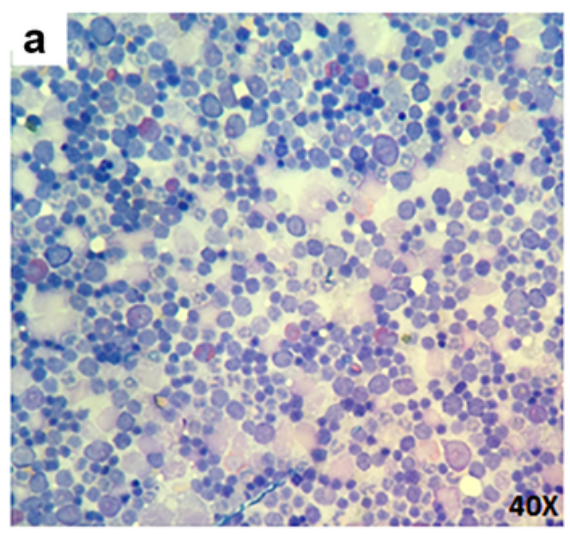

b
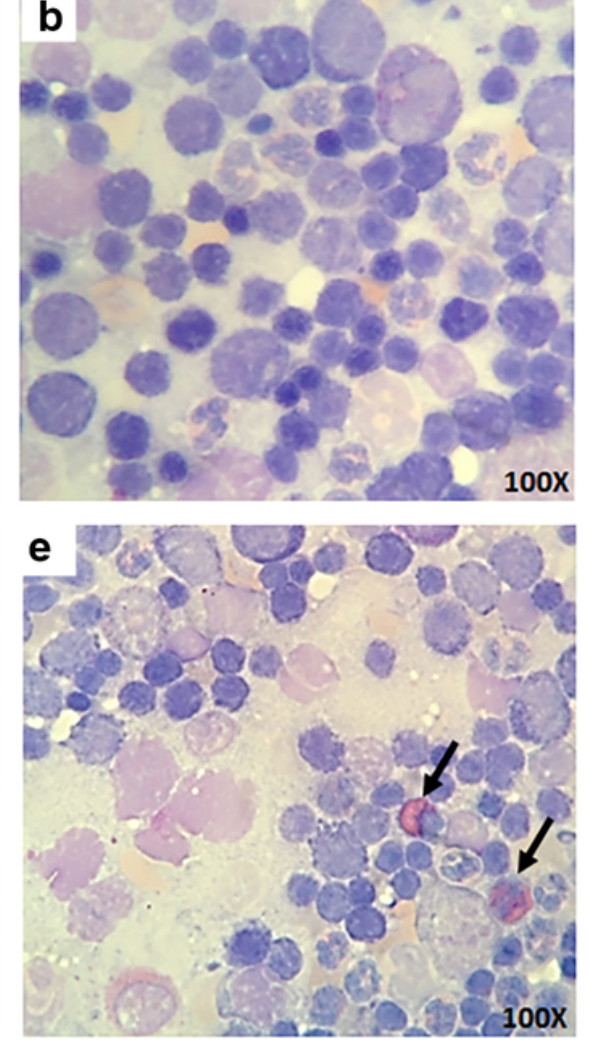

\section{Perls Prussian blue}
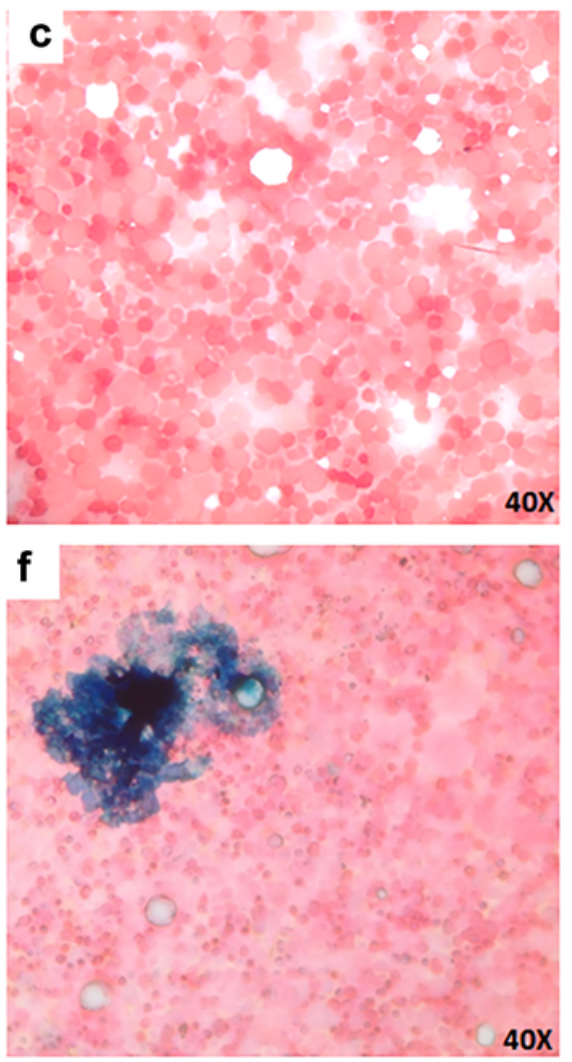

\section{Figure 6}

Perls' Prussian blue staining showing iron deposits in bone marrow of immature rats perinatally exposed to GBH. Representative images of bone marrow cellularity in immature rats from control ( $A$ and $B$ ) and GBH-exposed group ( $\mathrm{D}$ and $\mathrm{E}$ ). Arrows showing increased eosinophil number in $\mathrm{GBH}$-exposed group (E). Iron deposits in the bone marrow of 15-days-old rats from control and GBH-exposed group, (C) and (F), respectively. 8 animals from each experimental group were analyzed. (Images: 40X and 100X magnification). 

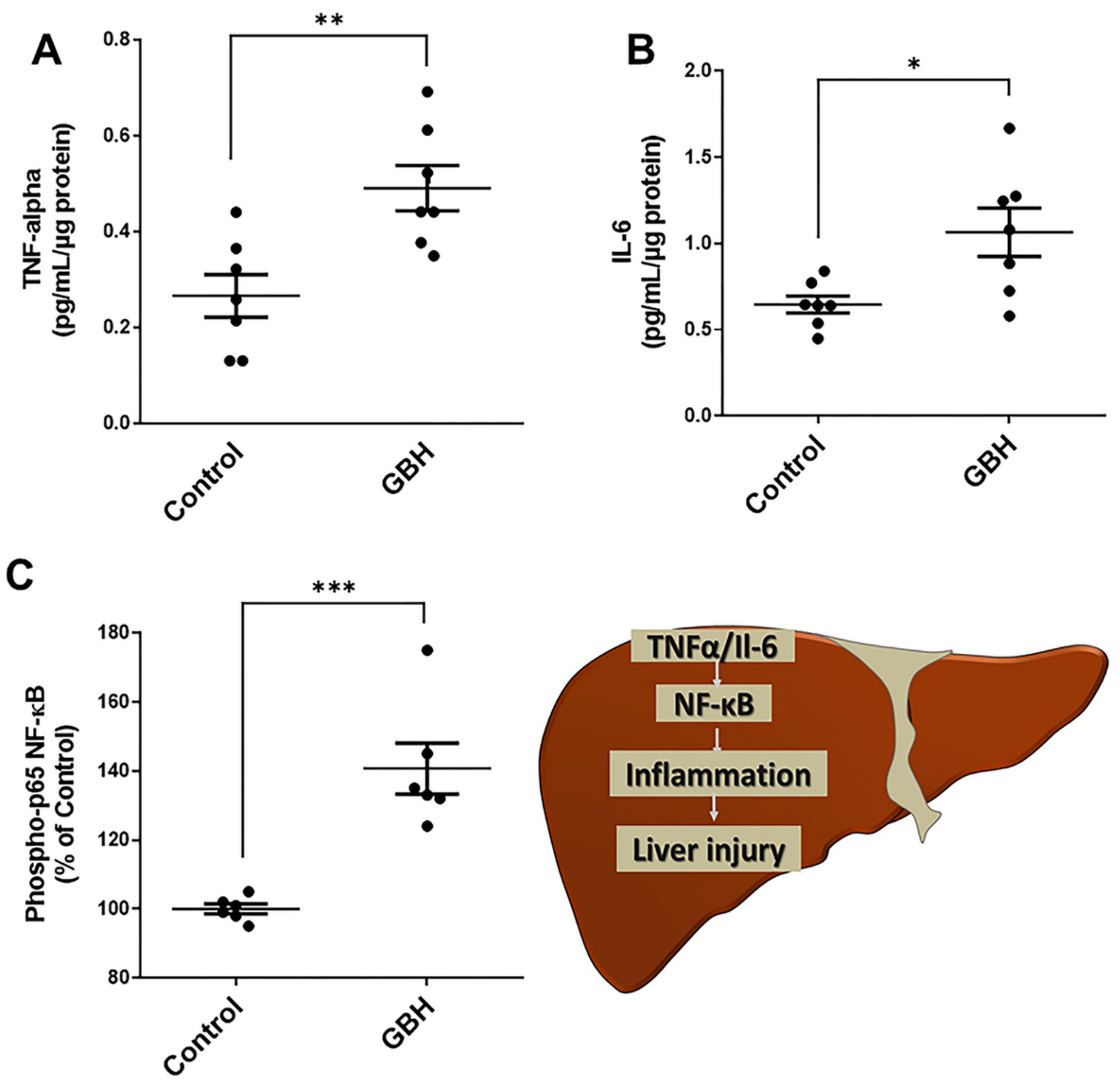

Figure 7

Effect of perinatal exposure to GBH on pro-inflammatory cytokines, interleukin-6 (IL-6) and tumor necrosis factor (TNF-alfa), and on p65-NF-kB pathway activation in liver of 15-days-old-rats. Liver slices were lysed and the levels of TNF-alfa (A), IL-6 (B) and phospho-p65 NF-KB (C) were determined by ELISA. Data are reported as means \pm SEM of 8 animals in each group. Statistically significant difference from controls, as determined by Student's t-test, are indicated: ${ }^{\star} p<0.05 ;{ }^{* \star} p<0.01,{ }^{\star \star *} p<0.001$. 


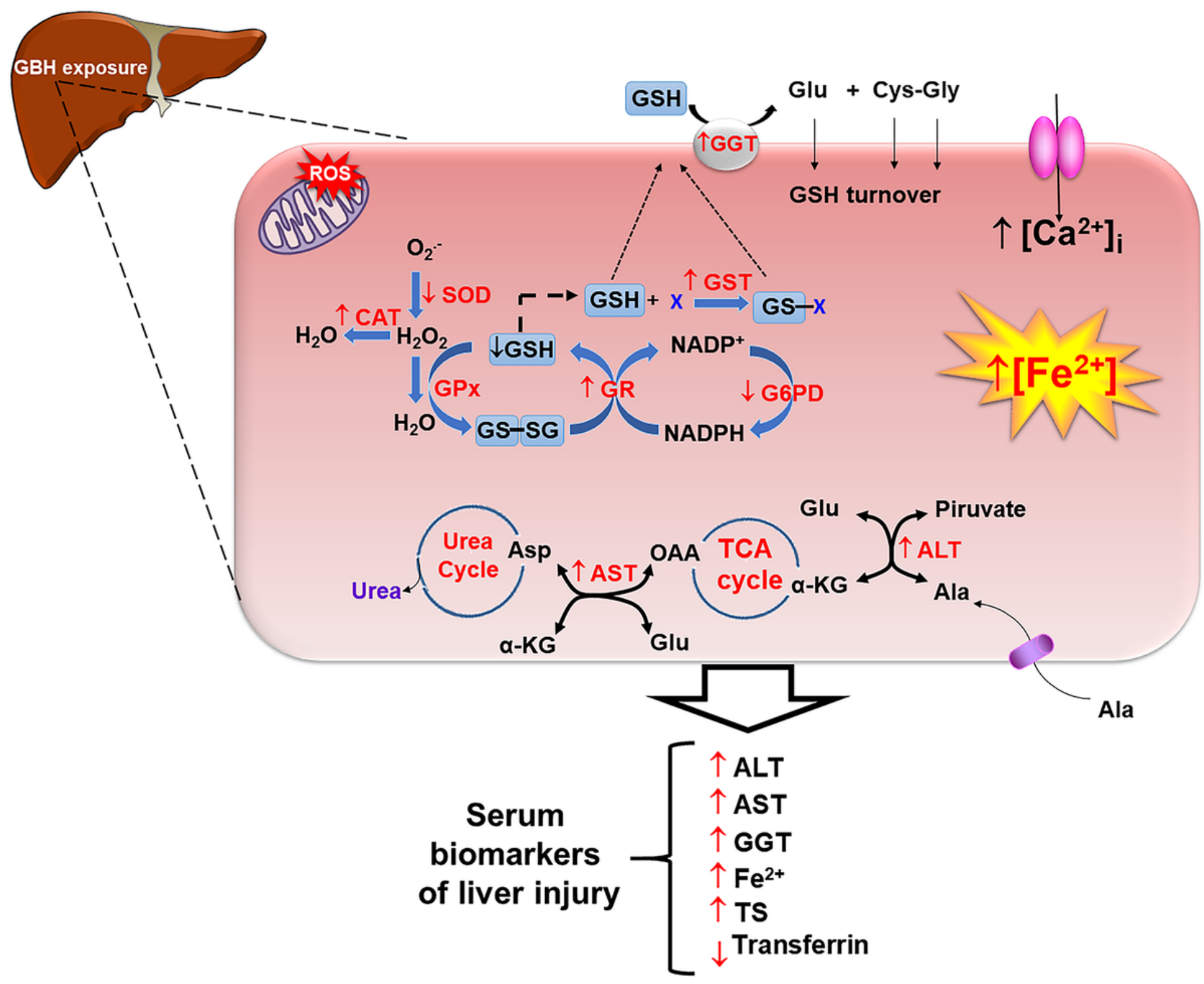

Figure 8

Proposed mechanism involved in hepatotoxic effects of perinatal GBH exposure on offspring's liver. The mechanism of perinatal toxicity of GBH to offspring's liver involves the increase of Ca2+ influx, oxidative stress induction, iron overload and inflammation. The disruption on calcium and iron homeostasis compromises the liver's antioxidant defense system leading to GSH depletion and hepatotoxicity. The glutamate metabolism was also altered in the liver GBH-exposed pups. The higher levels of the peripheral biomarkers of liver injury (iron, transferrin saturation, GGT, ALT and AST), associated with decreased concentrations of transferrin in offspring's serum, attested the toxicity of perinatal exposure to $\mathrm{GBH}$ to offspring liver, which may account to the tissue iron accumulation and induce early epigenetic changes that could lead to adverse outcomes later in life. The iron accumulation observed in the present study may be involved, at least in part, to GBH-induced neurotoxicity and neurobehavioral dysfunctions 
previously demonstrated by our group. $T S=$ transferrin saturation; $O A A=$ oxaloacetate; $a-K G=a-$ ketoglutarate; TCA = tricarboxylic acid cycle, $\mathrm{X}=$ xenobiotic . 